\title{
CONTROL POR LA DGRN DE LA CERTIFICACIÓN DE NACIMIENTO EXTRANJERA Y LA APLICACIÓN IMPERATIVA DE LA PRESUNCIÓN DE LA PATERNIDAD DEL MARIDO DE LA MADRE*
}

\author{
THE FOREIGN BIRTH CERTIFICATE'S CONTROL BY THE \\ DGRN AND THE IMPERATIVE APPLICATION OF THE \\ PATERNITY PRESUMPTION OF THE MOTHER'S HUSBAND
}

\author{
Carmen Ruiz SutiL \\ Profesora titular de Derecho internacional privado \\ Universidad de Granada \\ ORCID ID: 0000-0001-5063-1845
}

Recibido: 13.06.2020 / Aceptado: 01.07.2020

DOI: https://doi.org/10.20318/cdt.2020.5629

\begin{abstract}
Resumen: La mención del dato del padre recogido en un Registro extranjero y su acceso en la inscripción de nacimiento del Registro Civil español viene suscitando lo que hemos denominado como filiación contradictoria, problemática que trae causa en la presunción de paternidad del marido de la madre cuando los cónyuges ya se hallan separados de hecho en la época del nacimiento del hijo. El rechazo de la inscripción de la paternidad -cuando se incorpora en un título extranjero- origina una abundante doctrina de la DGRN, que afecta principalmente a las inscripciones de nacimiento de un importante sector de naturalizados españoles, además de entorpecer el derecho de opción y la atribución a la nacionalidad española del descendiente de sujeto español. Dicho resultado se debe a la aplicación como norma imperativa de la regla sustantiva de la presunción de paternidad matrimonial que lleva a cabo la autoridad registral española en el control de la filiación contenida en la certificación extranjera. Este estudio servirá, por un lado, para evidenciar la necesidad de mejorar la constatación de la paternidad del nacido de progenitor diferente al marido de la madre y, por otro lado, para ofrecer soluciones que atenúen las situaciones claudicantes de filiación que surgen a raíz de las circunstancias expuestas.

Palabras clave: filiación contradictoria, presunción de paternidad del marido de la madre, certificado del Registro Civil extranjero, art. 9.4 Cc español.
\end{abstract}

\begin{abstract}
The mention of the datum of the father collected in a foreign registry and its access to the birth registration in the Spanish Civil Registry has been raising the issue of the contradictory double filiation. This question derives from the paternity presumption of the mother's husband when the spouses are already de facto separated by the time the child is born. The refusal of the paternity inscription when included in a foreign act, originates an abundant doctrine of the DGRN. This mainly affects the birth certificates of an important sector of naturalized Spaniards. It also hinders the right of choice and the attribution of the Spanish nationality to Spaniards' descendants.
\end{abstract}

\footnotetext{
"ruizsuti@ugr.es

Este trabajo se enmarca dentro del Proyecto de Investigación $\mathrm{I}+\mathrm{D}+\mathrm{i}$ que lleva como título "Movilidad internacional de personas: el impacto jurídico-social en España y en la UE de la adquisición de la nacionalidad española por la población inmigrante", con código DER2016-75573-R.
} 
This result is mainly due to the imperative application of the substantive rule of the marital paternity presumption led by the Spanish Registration authority regarding the filiation control in the foreign certificates. This study will serve, on one hand, to demonstrate the need to improve the paternity of the child born to a father different from the mother's husband and, on the other hand, to offer solutions that mitigate the claudicate filiation situations arising from the circumstances exposed.

Keywords: contradictory filiation, presumption of the paternity of the mother's husband, Certificate from the Foreign Civil Registry and Art. 9.4 of the Spanish Civil Code.

Sumario: I. Introducción. II. La destrucción de la presunción de paternidad del marido de la madre en Derecho comparado. 1. La presunción de la paternidad matrimonial y su destrucción en el ordenamiento español. 2. La presunción de paternidad matrimonial y las vías para desvirtuarla en las legislaciones iberoamericanas. 3. La presunción de paternidad legítima y el sistema severo de su destrucción en los ordenamientos jurídicos de base islámica. III. Las inscripciones de nacimiento en el Registro Civil español y el acceso de la paternidad contenida en certificación extranjera. 1. La inscripción de nacimiento en España y la paternidad constatada en el extranjero. 2. Control de las certificaciones de nacimiento extranjeras. 3. La aplicación del art. 9.4 Cc en el ámbito registral. IV. Consecuencias de la filiación paterna contradictoria en el acceso a la nacionalidad española. 1. Importancia de la inscripción del dato de paternidad en la atribución/opción a la nacionalidad española y en los naturalizados españoles. 2. Valoración de la postura de la DGRN. V. Conclusiones.

\section{Introducción}

1. La repercusión de la globalización en las relaciones personales, el incremento de matrimonios y de parejas de distinta nacionalidad, así como el aumento del sector de población naturalizada española vienen ocasionando situaciones que presentan una especial trascendencia en el acceso al Registro civil español. Una de ellas es, precisamente, la que deriva de la paternidad consignada en la inscripción del nacimiento ${ }^{1}$ del que opta o se le atribuye la nacionalidad española y del ya nacionalizado español ${ }^{2}$, cuestión que será abordada en este estudio.

2. Si el dato del padre viene incorporado en una certificación de nacimiento extranjera, además de superar las garantías referidas a la regularidad extrínseca e intrínseca para ser reconocida, la Dirección General de los Registros y del Notariado (en adelante DGRN) vigila la presunción de paternidad matrimonial, pese a que la madre del interesado puede encontrarse separada de hecho de su marido en la época del nacimiento.

3. En estos casos, la resistencia a inscribir la mención de la paternidad en el Registro español conduce a la no anotación del apellido paterno y a la negación del resto de efectos vinculados a los deberes y obligaciones derivados de la patria potestad. Un sector importante de afectados es el de los ciudadanos naturalizados españoles, ya que tal negación no solo produce una falta de correspondencia entre la identificación registral española y la procedente del extranjero. Además, dicho rechazo entorpece el derecho de opción o la atribución de la nacionalidad española de los descendientes del sujeto español, dejando sin la posible doble nacionalidad a personas que podrían serlo.

${ }^{1}$ La nueva LRC suprime el tradicional sistema de división del Registro Civil en Secciones —nacimientos, matrimonios, defunciones, tutelas y representaciones legales - y crea un registro individual para cada persona a las que, desde el momento de su nacimiento o desde la adquisición de nacionalidad, se le asigna un código personal de ciudadanía (CPC).

${ }^{2}$ En relación con el que adquiere la nacionalidad española, estos pueden solicitar, en el momento de levantarse el acta de juramento o promesa de fidelidad al Rey y obediencia a la Constitución y a las Leyes, que se extienda la inscripción de nacimiento en el Registro Civil Municipal correspondiente al domicilio en el que se haya instruido el oportuno expediente registral. En otros casos, se estará a la regla general prevista en el art. 16 de la Ley del Registro Civil y art. 68 del Reglamento que la desarrolla, según los cuales "los nacimientos [...] se inscribirán en el Registro Municipal o Consular del sitio en que acaecen [...]. Cuando sea competente un Registro Consular, si el promotor está domiciliado en España, deberá practicarse antes la inscripción en el Registro Civil Central. 
4. Las situaciones originadas por la paternidad contradictoria en supuestos de tráfico externo afectan, en particular, a ciudadanos originarios de Iberoamérica, afirmación esta que procede de la existencia de una abundante doctrina en las Resoluciones de la DGRN ${ }^{3}$. Con menor incidencia, el Centro Directivo también se pronuncia sobre la inscripción de la paternidad de personas procedentes de Marruecos $^{4}$, Senegal $^{5}$ o de República Federal de Nigeria ${ }^{6}$.

5. Ello nos conduce a contrastar la regulación de la presunción de paternidad recogida en el sistema español con la existente en ciertos ordenamientos jurídicos extranjeros, a fin de comprobar los medios más o menos flexibles para su destrucción, al margen de un proceso judicial. La normativa actual española no ofrece la posibilidad de revertir estas situaciones de manera inmediata, a menos que se acuda a un procedimiento judicial de reclamación/impugnación de filiación. Esto prolonga la ausencia de paternidad jurídica hasta alcanzar una solución definitiva basada en una resolución judicial. Dicha problemática cobra especial importancia en el contexto de los expedientes registrales de inscripciones de nacimiento de personas originarias de países iberoamericanos, particularmente procedentes de Colombia $^{7}$, Ecuador $^{8}$, Honduras $^{9}$, Perú $^{10}$, República Dominicana ${ }^{11}$ o Venezuela ${ }^{12}$, destacando especialmente las certificaciones de nacimiento procedentes de $\mathrm{Cuba}^{13}$.

6. Igualmente, evidenciaremos que existe un cierto abandono en la práctica registral sobre el tratamiento de la filiación acerca de las situaciones privadas internacionales. No obstante, con la próxima entrada en vigor del art. 98 de la Ley 20/2011 de 21 de julio, del Registro Civil ${ }^{14}$ (en adelante LRC 20/2011), la autoridad registral española quedará obligada a constatar los datos de filiación contenidos

\footnotetext{
${ }^{3}$ Se puede comprobar en las últimas publicaciones de las RDGRN en el Boletín del Ministerio de Justicia, tales como RDGRN (4ª) de 17 de mayo de 2019, Boletín del Ministerio de Justicia, Año LXXIV, núm. 2.229, abril de 2020, pp. 18-21; RDGRN (6 4 de abril de 2019, Boletín del Ministerio de Justicia, Año LXXIV, núm. 2.228, marzo de 2020, pp. 9-11, entre otras muchas.

${ }^{4}$ Como la RDGRN (2a) de 3 de noviembre de 2017, Boletín del Ministerio de Justicia, Año LXXII, núm. 2213, noviembre de 2018, pp. 52-56; la RDGRN (103ª) de 19 diciembre de 2014, Boletín del Ministerio de Justicia, Año LXIX, del 1 al 31 de diciembre de 2014, pp. 25-28; la RDGRN (1 $\left.{ }^{\text {a }}\right)$ de 26 enero de 2009, Boletín del Ministerio de Justicia, Año LXIV, marzo de 2010, pp. 154-56.

${ }_{5}^{5}$ En la RDGRN (3 $3^{\text {a }}$ de 4 septiembre 2015, Boletín del Ministerio de Justicia, Año LXX 26 de Enero de 2016, pp. 24-27, donde se llega a resolver que no procede la atribución de filiación paterna no matrimonial de un español respecto de la menor nacida en 2013, asegurando que, a pesar de que la madre senegalesa estaba casada con otro senegalés en el momento del nacimiento de su hija, se encontraban separados de hecho desde hace años.

${ }^{6}$ RDGRN (26a) de 23 de febrero de 2018, Boletín del Ministerio de Justicia, Año LXXIII, núm. 2.215, enero de 2019, pp. 28-31, que con motivo de reconocimiento de la paternidad de un ciudadano nigeriano, se denegó tal inscripción por resultar la filiación contradictoria debido a la aplicación de la presunción legal del art. 116 del Cc.

7 Vid. RsDGRN (57ª) de 8 octubre de 2013, Boletín del Ministerio de Justicia, Año LXVIII, de 5 de febrero de 2014, pp. 8-9; (89 1 de octubre de 2014, Boletín del Ministerio de Justicia, Año LXIX, de 1 a 31 de octubre de 2014, pp. 16-18; (64 de 13 febrero de 2015, Boletín del Ministerio de Justicia, Año LXIX 19 de agosto de 2015, pp. 15-18; (2 $2^{\text {a }}$ de 28 de octubre de 2016, Boletín del Ministerio de Justicia, Año LXXI, núm. 2202, 6 de noviembre de 2017, pp. 27-30

8 RsDGRN (4ª) de 17 de mayo de 2019, Boletín del Ministerio de Justicia, Año LXXIV, núm. 2.229, abril de 2020, pp. 18-21; (46 ) de 14 de octubre de 2014, Boletín del Ministerio de Justicia, Año LXIX, del 1 al 31 de octubre de 2014, pp. 39-42; $\left(40^{a}\right)$ de 5 de septiembre de 2012, Boletín del Ministerio de Justicia, Año XLVII, de 20 de marzo de 2013, pp. 4-6; (6 $\left.6^{a}\right)$ de 24 octubre de 2011, Boletín del Ministerio de Justicia, Año LXVI, 4 de abril 2012, pp. 4-5.

${ }^{9}$ RDGRN (85) de 30 marzo 2015, Boletín del Ministerio de Justicia, Año LXIX, 19 de agosto de 2015, pp. 55-58.

${ }^{10}$ RsDGRN ( $8^{a}$ ) de 21 de diciembre de 2011, Boletín del Ministerio de Justicia, Año LXVI, 3 de mayo 2009, pp. 7-9; de 13 diciembre 2001 (JUR 2002\90079).

${ }^{11}$ RDGRN (32a) de 29 octubre de 2014, Boletín del Ministerio de Justicia, Año LXIX, del 1 al 31 de octubre de 2014.

${ }^{12}$ RsDGRN 4a de 4 junio de 2007 (JUR 2008\263996) y (4a) de 9 de julio de 2008, Boletín del Ministerio de Justicia, Año LXIII, agosto 2009, pp. 103-107; RDGRN (13 $)$ de 27 de marzo de 2015, Boletín del Ministerio de Justicia, Año LXIX, 19 de agosto de 2015, pp. 18-21; RsDGRN (47 ) y (48 $)$ de 27 de marzo de 2015, Boletín del Ministerio de Justicia, Año LXIX, 19 de agosto de 2015, pp. 509-518; 46ª de 20 de noviembre de 2015, Boletín del Ministerio de Justicia, Año LXX, 4 de mayo de 2016, pp. 294-299.

${ }^{13}$ Muestra de ello son las últimas publicaciones de las RsDGRN (6 $6^{\text {a }} 4$ de abril de 2019, Boletín del Ministerio de Justicia, Año LXXIV, núm. 2.228, marzo de 2020, pp. 9-11; $\left(3^{\mathrm{a}}\right)\left(4^{\mathrm{a}}\right)\left(5^{\mathrm{a}}\right)\left(6^{\mathrm{a}}\right)\left(7^{\mathrm{a}}\right)\left(12^{\mathrm{a}}\right)$ y $\left(13^{\mathrm{a}}\right)$ de julio de 2018 , Boletín del Ministerio de Justicia, Año LXXIII, núm. 2.219, mayo de 2019. pp.152-167

${ }^{14}$ BOE núm. 175, de 22 de julio de 2011.
} 
en una certificación registral extranjera, así como lo relativo a su validez formal (art. $11 \mathrm{Cc}$ ) y a la capacidad $($ art. $9.1 \mathrm{Cc}$ ) de las partes intervinientes. En este tipo de controles abordaremos la cuestión menos pacífica, concretamente nos referimos al control de la paternidad contenida en el título extranjero aportado conforme al ordenamiento designado por el art. 9.4 del Cc.

7. Por último, queremos advertir que, en esta ocasión, nuestro estudio no se adentrará en la problemática de los efectos beneficiosos del Derecho de la nacionalidad y de la extranjería en relación a la filiación de conveniencia, asunto clásico y suficientemente señalado por la doctrina, por la práctica registral y por la jurisprudencial ${ }^{15}$.

\section{La destrucción de la presunción de paternidad del marido de la madre en Derecho comparado}

8. Cada ordenamiento jurídico organiza un esquema normativo de filiación, poniendo en juego las reglas y criterios derivados de la coexistencia de los principios que la rigen (favor veritatis, igualdad de las filiaciones y favor filii, entre otros). Con ese contexto, los ordenamientos jurídicos estatales prestigian la presunción pater is est, aunque marcan distintos plazos para su vigencia y prevén los medios de destruirla, que encuentran una justificación suficiente, objetiva y razonable ligada a los diversos modos de concebir su tipo de familia.

9. La mayor parte de las legislaciones comparadas objeto de este estudio han seguido los plazos legales mínimos de 180 días desde la celebración del matrimonio y máximo de 300 días a partir su disolución para vincular la paternidad al marido de la madre, con alguna inapreciable variación. Lo que sí resulta heterogéneo son las vías existentes para desvirtuar la presunción de la filiación matrimonial, al margen de las acciones judiciales de filiación que existan al respecto y que, a continuación, procedemos a señalar.

\section{La presunción de la paternidad matrimonial y su destrucción en el ordenamiento español}

10. El art. 116 de nuestro $\mathrm{Cc}$ recoge distintos supuestos en los que opera la presunción de paternidad matrimonial del marido de la madre ${ }^{16}$ para el nacido después de la celebración del matrimonio y antes de los 300 días siguientes a su disolución, separación legal o de hecho de los cónyuges. Dicha presunción también es aplicable si el hijo nace dentro de los 180 días siguientes a la celebración del matrimonio, según el art. $117 \mathrm{Cc}$ español. A pesar de que falten los requisitos, si existe voluntad de los progenitores, se puede defender la paternidad matrimonial, tal y como establece el art. $118 \mathrm{del} \mathrm{Cc}$ español. Asimismo, puede que la filiación matrimonial sea sobrevenida si la filiación originaria se determinó registralmente como extramatrimonial (art. $120 \mathrm{Cc}$ español) pero, con posterioridad, se celebra el matrimonio entre los progenitores (art. 119 Cc español). En todo caso, si el alumbramiento sucede más

${ }^{15}$ Ma . C. Gete-Alonso y Calera, "Reconocimiento de complacencia; impugnación de la filiación e impugnación del reconocimiento, (a propósito de la sentencia del Tribunal Superior de Justicia de Cataluña -sala de lo civil- de 16 de diciembre 1997)", Tribunal, 1997-III, pp. 33-50; F. Rivero HernáNDEZ, "Los reconocimientos de complacencia (Con ocasión de unas sentencias recientes)", Anuario de Derecho Civil, vol. 58, núm. $3^{\circ}$, julio/septiembre de 2005, pp. 1049-1113; Id., "La filiación en el umbral del siglo XXI", Revista de la Facultad de Derecho Univ. Gr., 2001, núm. 4, pp. 99-141, en espec. pp. 135-136; C. Ruiz Sutı, "Las filiaciones de complacencia en los derechos de extranjería y nacionalidad", Revista de Derecho Migratorio y Extranjería, Julio de 2010, núm. 24, pp. 37-53.

${ }^{16}$ El Cc español no regula presunción para la paternidad no matrimonial. En cambio, si existe en los Derechos forales, como sucede con el art. 235-10, de la Ley 25/2010, de 29 de julio, del libro segundo del Código civil de Cataluña, relativo a la persona y la familia, que viene a decir que se presume que es padre del hijo no matrimonial, el hombre con el que la madre ha convivido en el periodo legal de la concepción, el hombre con el que la madre ha mantenido relaciones sexuales en el periodo de la concepción, el hombre que ha reconocido la paternidad tácitamente. 
allá de los 300 días siguientes a la disolución o a la separación legal o de hecho de los cónyuges ${ }^{17}$, deja de aplicarse la presunción marital ${ }^{18}$.

11. Centrándonos en la calificación que lleva a cabo el Encargado del Registro Civil español para la inscripción de la paternidad no matrimonial del nacido de madre casada ${ }^{19}$, en uso de las facultades que le confiere el art. 28 LRC y antes de extender el asiento, se comprueba que dicha presunción queda desvirtuada a los efectos de demostrar que no entra en juego la presunción de paternidad del marido de la madre del art. 116 Cc español.

12. La solución actual, en aplicación del último párrafo del art. 44.4 de la Ley 20/2011, de 21 de julio, del Registro Civil ${ }^{20}$, de acuerdo con la redacción establecida por la Ley 19/2015, de 13 de julio, de medidas de reforma administrativa en el ámbito de la Administración de Justicia y del Registro Civil21, va encaminada a que, en la inscripción de nacimiento no se constate el dato del padre cuando se declare la filiación de otra persona distinta del marido de la madre. Únicamente se inscribirá la materna, cuya identidad se acredita mediante el parte facultativo y, a continuación, se procederá a la apertura de un expediente registral gubernativo ${ }^{22}$ para determinar la filiación paterna. Por consiguiente, a pesar de la fuerza probatoria recogida en el art. $113 \mathrm{Cc}$ de la presunción de paternidad del marido de la madre, ya no es obligado inscribir la filiación matrimonial ${ }^{23}$.

13. Tanto en la calificación del Encargado como en el expediente gubernativo, el régimen de prueba es bastante amplio para admitir la existencia de separación legal o de hecho de los cónyuges al menos trescientos días antes del nacimiento, al margen de las controversias doctrinales sobre la admisión de las mismas ${ }^{24}$. La Circular de 2 de junio de 1981 de la DGRN sobre régimen legal de la filiación ${ }^{25}$ advirtió que no bastaba "la simple declaración de que marido y mujer tienen domicilios distintos..., sino que es precisa una prueba efectiva de la interrupción de la vida conyugal”. Las pruebas a aportar pueden ser desde documentales (certificados de empadronamiento y convivencia; fecha de presentación

\footnotetext{
${ }^{17}$ Debemos aclarar que el cómputo del plazo máximo de vigencia de la presunción de paternidad se realiza a partir del cese efectivo de la vida conyugal y no desde que la sentencia sea firme. En este sentido, vid. la RDGRN de 22 de mayo de 1991, recogida por Ma. D. Férez Fernández y M. GarRiga Gorina, "La presunción de paternidad matrimonial del artículo 116 en el caso de separación de hecho. Comentario a la RDGRN de 22 de mayo de 1991", Revista Jurídica de Cataluña, 1992, vol. 91, núm. 4, pp. 1065-1076; I. Cordero Cutillas, "Presunción de Paternidad (arts. 116 y 117 CC)", en L. Martínez Vázquez DE CASTRo (coord.), Historia y derecho: estudios jurídicos en homenaje al profesor Arcadio García Sanz, Valencia, Tirant Lo Blanch, 1995, pp. 201-220, en espec. 211.

${ }^{18}$ Por el contrario, el art. 235-5.2) del Código civil de Cataluña amplía los efectos de la presunción a los nacidos más allá de los 300 días siguientes a la disolución del matrimonio, siempre que se acredite y mediante toda clase de pruebas que los hijos nacieron de estas relaciones conyugales.

${ }^{19}$ Cuando se intenta inscribir por declaración dentro de plazo la declaración o se efectúa un reconocimiento voluntario de la paternidad no matrimonial de madre aún casada, es necesario que en Encargado realice averiguaciones, no en un expediente, sino en las diligencias comprobatorias de la calificación en el plazo de diez días (art. 28 LRC). Ello se efectúa con audiencia, si es posible, de los cónyuges o de sus herederos, a fin de cerciorarse de que el nacimiento del hijo acaeció pasados trescientos días desde la separación legal o de hecho de los cónyuges. Y ello para demostrar que no entra en juego la presunción de paternidad del marido y poder inscribir la filiación no matrimonial pretendida.

${ }^{20}$ BOE núm. 175, de 22 de julio de 2011.

${ }^{21} B O E$ núm. 167, de 14 de julio de 2015. Para ver la comparativa de la redacción anterior frente a la modificación contenida en el art. 2.1 de la Ley 19/20015 de medidas de reforma administrativa en el ámbito de la Administración y del Registro Civil véase $M^{a}$. C. Gete-Alonso y CALERA, "La inscripción de nacimiento en la Ley 20/2011. Entre el Derecho a la identidad de la persona y la reserva de la maternidad", Revista de Derecho Civil, vol. V, núm. 1 (enero-marzo), 2018, pp. 1-54, en espec. pp. 7 y 8.

${ }^{22}$ Estos expedientes están regulados por los arts. 97 Ley del Registro Civil y 341 y ss. del Reglamento del Registro Civil, comentados en F. Luces GIL, Derecho del Registro Civil, $5^{\text {a }}$ ed., Barcelona, edit. Bosch, 2002.

${ }^{23}$ Vid. la RDGRN (13 $)$ de 27 de marzo de 2015, Boletín del Ministerio de Justicia, Año LXIX, 19 de agosto de 2015, pp. $18-21$.

${ }^{24}$ En este sentido, entre otros, I. Cordero Cutillas, "Presunción de Paternidad...", loc. cit., p. 210; Id. "La impugnación de la paternidad matrimonial”, Colección de Estudios Jurídicos, núm. 6, Castellón, Publicación de la Universidad Jaime Primero, 2001, pp. 36-37; M. Peña Bernaldo de Quirós, "Comentario a los artículos 108 a 141 del Código civil (De la paternidad y filiación)”, Comentarios a las Reformas del Derecho de Familia, vol. I, Madrid, Tecnos, 1984, pp. 774-1023, en espec. p. 867.

${ }^{25}$ BOE núm. 134, de 5 de junio de 1981.
} 
de la demanda de separación, nulidad o divorcio, con el efecto de cesar la presunción de convivencia conyuga ${ }^{26}$ ) e, incluso, la propia declaración del marido ${ }^{27}$. En ocasiones, incluso los certificados de movimientos migratorios de ambos cónyuges ayudan a verificar que el marido permanecía en el extranjero, mientras la mujer se encontraba en otro país en el tiempo en el que pudo producirse el embarazo ${ }^{28}$. En cuanto a las pruebas de ADN, la DGRN indica que el dicho dictamen pericial no puede ser valorado en vía administrativa del expediente gubernativo a efectos de determinar la filiación paterna, debiendo ser solicitado y apreciado en vía judicial ${ }^{29}$.

14. Ahora bien, en este tipo de expedientes registrales no puede existir oposición de parte interesada o del Ministerio Fiscal. Si es así, la filiación paterna pretendida no quedará determinada por la vía de un expediente gubernativo, sino que se tendrá que acudir al procedimiento judicia $\mathrm{l}^{30}$ conforme a los arts. 764 y siguientes de la Ley de Enjuiciamiento Civil y ejercitar la correspondiente acción de los arts. 133 y 136 CC, según la nueva redacción de la Ley 26/2015, de 28 de julio, de protección a la infancia y la adolescencia ${ }^{31}$.

15. Como observamos, el Derecho español, a pesar de las reformas que se han llevado a cabo en materia de filiación, orientadas al predominio de la verdad biológica, en coordinación con la necesaria seguridad jurídica que debe imperar en materia de estado civil, existe cierta incertidumbre en la aplicación de la presunción de paternidad matrimonial y su sistema de destrucción, pues el hijo podría encontrarse con un periodo sin filiación acreditada debido a la paternidad contradictoria. En la legislación alemana existe una solución que evita dichas situaciones de inseguridad jurídica. De esta manera, la regulación española podría seguir el modelo establecido en el art. 1599.2) del BGB que viene a disponer que: “...las presunciones de paternidad matrimonial recogidas en la Secciones 1592.1 y 1593 del BGB no se aplican si el niño nace después de la demanda de divorcio cuando se reconozca por un tercero conforme a la Sección 1594 BGB ..., incluso si el matrimonio no es disuelto hasta un año desde la petición del divorcio y siempre que el ex esposo otorgue su consentimiento a dicho reconocimiento" 32 .

16. En definitiva, consideramos que el sistema español está necesitado de una actualización legislativa en materia de filiación. Para todos los modelos de familia, se debería instaurar presunciones

${ }^{26}$ En la RDGRN (1 $1^{\text {a }}$ de 26 enero de 2009, Boletín del Ministerio de Justicia, Año LXIV, marzo de 2010, pp. 154-56, con objeto de desvirtuar la presunción de paternidad matrimonial de una menor de madre marroquí, se aporta el acta de repudio formalizado conforme Derecho marroquí y la certificación relativa al hecho de no haber contraído la madre posterior matrimonio. Este tipo de pruebas no alcanza a excluir toda duda razonable sobre la posible paternidad del ex marido de la madre, por lo que se inscribe el nacimiento de la menor, aunque sin filiación paterna. Por su parte, la RDGRN (2a) de 3 de noviembre de 2017 , Boletín del Ministerio de Justicia, Año LXXII, núm. 2213, noviembre de 2018, pp. 52-56, en la que se solicitó la inscripción de nacimiento de su hijo con el único dato de la filiación materna, alegando que, si bien la madre se encontraba casada con ciudadano marroquí desde septiembre de 2012, estaban separados de hecho desde hacía más de 300 días desde que se produjo el nacimiento. Finalmente, se consideró que no se encontraba acreditada suficientemente la separación de los cónyuges y se estima que las actuaciones deben iniciarse en vía judicial a efectos de la determinación de la filiación paterna del menor.

${ }^{27}$ Vid. M. Corera Izu, "El asiento de nacimiento en la nueva Ley del Registro Civil. La problemática de la filiación”, Diario La Ley, núm. 8686, Sección Tribuna, 21 de enero de 2016, Ref. D-30, La Ley (LA LEY 36/2016).

${ }^{28}$ Tal y como se aportó como prueba en la RDGN $\left(6^{\mathrm{a}}\right)$ de 24 de octubre de 2011, Boletín del Ministerio de Justicia, Año LXVI, 4 de abril 2012, pp. 4-5, donde se expone en el FJ ${ }^{\circ}$ III lo siguiente: “En este caso el nacimiento tuvo lugar el 22 de marzo de 2009, resultando probado mediante las correspondientes certificaciones de movimientos migratorios que la madre salió de Ecuador el 25 de mayo de 2008, habiendo permanecido en España desde entonces, y que, por el contrario, su exmarido, con el que continuaba casada en el momento del nacimiento del menor, no registra movimiento migratorio alguno, por lo que queda acreditado que la separación de hecho de los cónyuges fue anterior en más de trescientos días a la fecha del alumbramiento. Por lo tanto, no rige en este caso la presunción legal de paternidad del marido de la madre y no debe inscribirse una filiación matrimonial no determinada legalmente".

${ }^{29} \mathrm{M}^{\mathrm{a}}$. I. De La IgLESIA MonJe, "Insuficiencia de la prueba biológica de paternidad para desvirtuar la presunción de filiación matrimonial en sede gubernativa a los efectos de la inscripción (Comentario de la DGRN de 23 de mayo de 2007)", Revista Crítica de Derecho inmobiliario, núm. 704, nov.-dic. 2007, 2718-2724.

${ }^{30}$ Véase al respecto el $\mathrm{FJ}^{\mathrm{o}} \mathrm{V}$ de la RDGRN $\left(8^{\mathrm{a}}\right)$ de 21 de diciembre de 2011, Boletín del Ministerio de Justicia, Año LXVI, 3 de mayo 2009, pp. 7-9.

${ }^{31}$ BOE núm. 180, de 29 de julio de 2015.

${ }^{32}$ Traducción propia. El texto en alemán e inglés se puede consultar en Red Española de Derecho privado y comparado, http://civil.udg.edu/php/index.php?id=526 
específicas y plurales aplicables a los efectos de emplazar y desplazar los vínculos familiares que genera la presunción de paternidad matrimonial. De igual manera, correspondería implantar un sistema de destrucción más práctico que permita a los interesados no tener que acudir a las respectivas acciones judiciales. Ante las nuevas realidades, quizás no sea un despropósito reflexionar sobre la incorporación de la prueba de $\mathrm{ADN}$ a los procesos administrativos/registrales ${ }^{33}$, además de la vía judicial ordinaria. Desde luego, si el legislador español asume esta solución, tendría que reestructurar el vigente estatus legal, que reserva dicha prueba científica al ámbito judicial y reflexionar sobre los derechos fundamentales afectados, como la dignidad de la persona y el libre desarrollo de la personalidad del hijo (art. $10 \mathrm{CE}$ ) y el derecho fundamental a la intimidad personal y familiar del progenitor (art. $18 \mathrm{CE}$ ) y la protección de datos personales al respecto. Lo cierto es que encontrar un justo equilibrio entre la búsqueda de la verdad biológica y la estabilidad del estado civil de filiación y que coincida con el interés general en la seguridad jurídica es una tarea difícil de conseguir.

\section{La presunción de paternidad matrimonial y las vías para desvirtuarla en las legislaciones ibe- roamericanas}

17. Los sistemas jurídicos iberoamericanos, aunque pertenezcan a esferas regionales distintas, tienen en común la tradición española, lo que motiva que la figura de la presunción de la filiación paterna matrimonial se regule de forma semejante a la existente en el Cc español, aunque con matices singulares propios de cada ordenamiento.

18. En principio, existe cierta unanimidad en las legislaciones objeto de comparación en relación con la fórmula de fijar un plazo mínimo para que comience a regir la presunción de la paternidad matrimonial. Por un lado, al igual que dispone el art. 116 del Cc español, las normas que recogen que el padre es el marido de la madre si el hijo nace a partir de los 180 días contados desde el matrimonio son los arts. 179 Código de Familia (en adelante CF) boliviano ${ }^{34}$; 92 y 214 Código Cc colombiano $^{35}$; 69, segundo párrafo $\mathrm{CF}$ costarricense ${ }^{36} ; 233 \mathrm{Cc}$ ecuatoriano ${ }^{37}$; $199.1 \mathrm{Cc}$ guatemalteco ${ }^{38} ; 324$ del Cc mexicano ${ }^{39} ; 200 \mathrm{Cc}$ nicaragüense ${ }^{40} ; 266$ y $267 \mathrm{CF}$ panameño ${ }^{41}$ o $215 \mathrm{Cc}$ uruguayo $^{42}$. Ahora bien, la imposición de un plazo mínimo para que comience a regir la presunción de paternidad conlleva una serie de problemas que se corrigen a través de fórmulas equivalentes a la instaurada en el art. 117 Cc español. Así, se establecen soluciones similares en los arts. $213 \mathrm{Cc}$ colombiano; $246 \mathrm{Cc}$ ecuatoriano; $328 \mathrm{Cc}$ mexicano o 216 Cc uruguayo, que favorecen la paternidad del que nace antes de los 180 días de la celebración del matrimonio cuando exista consentimiento de ambos progenitores.

${ }^{33}$ Sobre la práctica extrajudicial de pruebas biológicas, véase M. MANDOFia Berney, "L’expertise en paternité sur demande privée", Revue du droit de tutelle, 1998, pp. 137-138.

${ }^{34}$ Aprobado por Decreto Ley 10426 de 23/08/1972, elevado a rango de Ley 996 de 04/04/1988, http://www.gacetaoficialdebolivia.gob.bo. También se puede consultar el texto en https://bolivia.infoleyes.com/norma/656/codigo-de-familia-cf

${ }^{35}$ Art. 214 Cc colombiano modificado por el art. 2 de la Ley 1060, de 26 de julio de 2006 (Diario Oficial núm. 46.341, de 26 de julio de 2006), que establece lo siguiente: "El hijo que nace después de expirados los ciento ochenta días subsiguientes al matrimonio o a la declaración de la unión marital de hecho, se reputa concebido en el vínculo y tiene por padres a los cónyuges o a los compañeros permanentes, excepto en los siguientes casos: 1 . Cuando el cónyuge o el compañero permanente demuestre por cualquier medio que él no es el padre; 2 . Si en proceso de impugnación de la paternidad mediante prueba científica se desvirtúa esta presunción, en atención a lo consagrado en la Ley 721 de 2001".

${ }^{36}$ Aprobado por Ley $\mathrm{N}^{\circ} 5.476$ de 21 de diciembre de 1973, se puede consultar en http://www.pgrweb.go.cr/scij/Busqueda/ Normativa/Normas/nrm_texto_completo.aspx?param2=NRTC\&nValor1=1\&nValor2=970\&param2=1\&strTipM=TC\&1Result ado $=5 \& \operatorname{strSim}=\operatorname{simp}$

${ }^{37}$ Precepto sustituido por el artículo 26 de Ley No. 0, publicada en Registro Oficial Suplemento 526 de 19 de Junio del 2015

38 Aprobado por Decreto-Ley núm. 106, publicado en el Diario de Centro América el 07 de octubre de 1963.

${ }^{39}$ Diario Oficial de la Federación, del 31 de agosto de 1928.

${ }^{40}$ Reformado por Ley núm. 186, de 16 de noviembre de 1995.

${ }^{41}$ Redacción actual conforme a Ley N ${ }^{\circ} 30$ de 5 de mayo de 2015, que modifica y deroga disposiciones del Código de la familia (Gaceta Oficial Digital, 5 de mayo de 2015), en https://www.gacetaoficial.gob.pa/pdfTemp/27773 B/50671.pdf

${ }^{42}$ Ley núm. 16.603 de 19 de octubre de 1994, en https://parlamento.gub.uy/ 
19. Otros ordenamientos jurídicos recurren a un sistema más elástico de presunción de paternidad matrimonial, al no prever un plazo mínimo desde que se celebra el matrimonio para atribuir la paternidad, tal y como resulta de los arts. 566 del Cc y Comercial argentino ${ }^{43} ; 1.597 .1 \mathrm{Cc}$ brasileño ${ }^{44} ; 184$ del Cc chileno ${ }^{45}$; 69, primer párrafo CF costarricense; 74.1 del CF cubano ${ }^{46} ; 312$ Cc dominicano; $107.1 \mathrm{CF}$ hondureño ${ }^{47} ; 361$ del Cc peruano ${ }^{48} ; 113$ del Cc puertorriqueño $0^{49} 141$; CF salvadoreño $0^{50}$ o $201 \mathrm{Cc}$ venezolano ${ }^{51}$.

20. Más divergencias localizamos en la aplicación del plazo máximo de vigencia de la presunción de paternidad matrimonial, ya que cada ordenamiento lo regula de forma singular. Para contabilizar el final de los 300 días del periodo máximo, existe una fórmula análoga al art. 116 Cc español, como es enumerar expresamente las instituciones que sirven de referencia para el plazo conclusivo, tales como disolución, separación de hecho/judicial o divorcio. Las normativas que recogen dicha técnica son los arts. $566 \mathrm{Cc}$ y Comercial argentino ${ }^{52} ; 179$ CF boliviano ${ }^{53} 1.597$. II Cc brasileño ${ }^{54} ; 184$ de Cc chileno $^{55} ; 69$ CF costarricense; 315 Cc dominicano; 324.II completado por el $327 \mathrm{Cc}$ mexicano; $200 \mathrm{Cc}$ nicaragüense; 141.2 CF salvadoreño o $203 \mathrm{Cc}$ venezolano. Otras legislaciones prefieren aglutinarlas con un término más amplio, como sucede con el uso de la "disolución del matrimonio" de los arts. 220 Cc colombiano; 199.2 y 202 Cc guatemalteco; 113 Cc puertorriqueño o con la noción de "extinción del vínculo matrimonial" de los arts. 74.2 CF cubano o 107.2 Cc hondureño.

${ }^{43}$ Aprobado por Ley 26.994, promulgada el 7 de octubre de 2014 y publicada en el Boletín Oficial de la República de Argentina núm. 32985, de 18 de octubre de 2015.

${ }^{44}$ Ley núm. 10.406, de 10 de enero de 2002 (D.O.U. de 11 de enero de 2002), en http://legislacao.planalto.gov.br/legisla/ legislacao.nsf/Viw_Identificacao/lei\%2010.406-2002?OpenDocument

${ }_{45}$ Norma modificada por Ley 19947 (D.O. 17 de mayo de 2004). Véase el Código civil de Chile en https://www. leychile.cl/Consulta/nav_vinc_modificacion?idNorma $=1973 \&$ tipoParte $=0 \&$ idParte $=\&$ fechaVigencia $=1857-01-01 \&$ clase vinculacion=MODIFICACION; E. GANDULFo RAMíREZ, "Revisión de la paradoja de la regla de paternidad marital. Un examen analítico", Revista de Derecho. Escuela de Postgrado, núm. 5, julio 2014, pp. 85 - 118.

${ }^{46}$ Código de Familia aprobado por Ley núm. 1289 de 1975, en https://www.gacetaoficial.gob.cu/html/codigo\%20de\%20 lafamilia.html. La expresión "vida matrimonial" "alude también al matrimonio formalizado o reconocido judicialmente. Véase L. B. Pérez-Gallardo, "Luces y sombras entorno a la regulación jurídica de la filiación en Cuba", Vniversitas, Bogotá (Colombia), núm. 122, 2011, pp. 395-440, en espec. p. 403-406, cita 17, en http://www.scielo.org.co/scielo.php?script=sci arttext\&pi $\mathrm{d}=$ S0041-90602011000100014 (consulta: 23 de abril de 2019).

${ }^{47}$ Aprobado por Decreto núm. 76-84, publicado en el Diario Oficial La Gaceta núm. 24, 394 de 16 de agosto de 1984, en https://www.tsc.gob.hn/biblioteca/index.php/codigos/608-codigo-de-familia

${ }^{48}$ Precepto modificado recientemente por el Decreto legislativo núm. 1377 que fortalece la protección integral de niñas, niños y adolescentes (D.O. El Peruano, 24 de agosto de 2018)

${ }^{49}$ Precepto que fue modificado por Ley núm. 215 de 29 de diciembre de 2009, para enmendar los arts. 113, 114, 115, 116 y 117 del Cc de Puerto Rico, a fin de establecer las presunciones de paternidad y de maternidad; el derecho a impugnarlas; indicar quienes pueden llevar la acción de impugnación; fijar el término para ejercitarla o disponer el efecto retroactivo de la ley en los casos ante la consideración del Tribunal.

${ }^{50}$ Aprobado por Decreto núm. 677 (D. O. núm. 231, de 13 de diciembre de 1993).

${ }^{51}$ Gaceta núm. 2.990 Extraordinaria del 26 de Julio de 1982, consultado en https://www.iberred.org/legislacion-codigo-civil

${ }^{52}$ Que dispone: "se presumen hijos del o la cónyuge los nacidos... hasta los trescientos días posteriores a la interposición de la demanda de divorcio o nulidad del matrimonio, de la separación de hecho o de la muerte...". Sobre dicha legislación, vid. A. J. Bueres, Código Civil y Comercial de la Nación comentado, anotado y concordado, $1^{\mathrm{a}}$ ed., Buenos Aires, Hammurabi, 2014, p. 39, destaca que se mejora la redacción de este precepto en el nuevo Código, al clarificar que el plazo máximo durante el cual regirá la presunción comienza a contarse siempre desde la interposición de la demanda de divorcio o nulidad de matrimonio. Varios autores llaman la atención sobre la contradicción que supone mantener una presunción de filiación en el Código unificado, toda vez que en él se relativizan los deberes conyugales de «cohabitación y fidelidad». Cfr. J. C. RiverA y G. MEdina, "Nuevo Código Civil y Comercial Comentado", Buenos Aires, La Ley, 2014.

${ }^{53}$ Que dispone: “...dentro de los trescientos días siguientes a su disolución o invalidación. En éste último caso el plazo se cuenta desde el día posterior a la separación de los esposos. Se reserva la prueba contraria a la presunción indicada".

${ }^{54}$ Nacido dentro de los trescientos días de la disolución de la sociedad conyugal, por muerte,

separación legal, nulidad y nulidad matrimonial;

${ }^{55}$ La Ley núm. 19.947, que establece Nueva Ley de Matrimonio Civil (Boletín núm. 9604-18, de 17 de mayo de 2004) introdujo la separación de hecho y la separación judicial. Particularmente se dispuso la modificación del art. 184 Cc chileno para agregar de forma exclusiva la nueva figura de la "separación judicial" reconocida en sus arts. 26 y 27, como límite temporal de la regla de paternidad, dejando fuera la separación de hecho regulada en los arts. 21 a 25 de esta legislación. Vid. E. GANDULFo RAmírez, "Revisión de la paradoja de la regla de paternidad marital...", loc. cit. pp. 113-116, que critica esta solución, ya que la Ley de Matrimonio Civil incorporó la separación de hecho, por lo que resulta incomprensible no haber completado la normativa de filiación. 
21. Con la idea de evitar las paternidades contradictorias, cuando cesa la convivencia conyugal, los ordenamientos comparados acuden habitualmente a la vía judicial para la destrucción de la presunción de la filiación matrimonial, tal y como disponen los arts. 589 y siguiente del Cc y Comercial argentino; $184.2 \mathrm{Cc}$ chileno ${ }^{56} ; 214$ y siguientes Cc colombiano; 78 al $81 \mathrm{CF}$ cubano; $316,318 \mathrm{Cc}$ dominicano; $233,233 \mathrm{~A}^{57}, 245$ y $246 \mathrm{Cc}$ ecuatoriano; art. 330, $374 \mathrm{Cc}$ mexicano; 217 y $218 \mathrm{Cc}$ uruguayo o 206, 208, 226-234 Cc venezolano.

22. Existen legislaciones que evitan procesos judiciales de paternidad y recogen vías más flexibles para desvirtuar la presunción matrimonial cuando los cónyuges estuvieran separados de hecho. A modo de ejemplo, el art 141.2 CF salvadoreño emplea una técnica para no aplicar esta presunción en caso de que hubiera separación de hecho de los cónyuges por más de un año y el hijo hubiera sido reconocido por otra persona diferente al marido. Por su parte, el Cc peruano de $2018^{58}$ se sitúa en uno de los sistemas más avanzados, pues la nueva redacción de sus art. 361 y 362 establece que si el hijo nace durante los 300 días antes de quedar disuelto el matrimonio, la madre puede declarar que el padre no es su marido ante el Registro civil o la entidad de salud competente. El medio para que este hijo sea reconocido por su progenitor biológico viene de la mano del art. $396 \mathrm{Cc}$ peruano, que establece que "el hijo o hija de mujer casada puede ser reconocido por su progenitor cuando la madre haya declarado expresamente que no es de su marido. Este reconocimiento se puede realizar durante la inscripción del nacimiento cuando la madre y el progenitor acuden al registro civil, o con posterioridad a la inscripción realizada solo por la madre, cuando esta haya declarado quién es el progenitor. Procede también cuando el marido lo hubiese negado y obtenido sentencia favorable". Otro de los modelos para flexibilizar la aplicación de la presunción de filiación marital es el art. 269 CF panameño, que admite “...la declaración jurada de la madre y del padre biológico rendida ante el funcionario del Registro Civil, de que el marido no es el progenitor, sin perjuicio del derecho del esposo a ejercitar la acción de impugnación dentro del término de un año contado a partir de la inscripción..."

23. Lamentablemente, con la finalidad de evitar confusión de paternidades, persisten leyes que prohíben a la madre contraer matrimonios antes de que transcurran 300 días contados desde la disolución del anterior enlace o desde que se declare nulo, como ocurre en el art. 21.1 del CF hondureño. Otras legislaciones, obligan a la mujer divorciada o en pleno proceso de extinción del matrimonio a denunciar ante el juez el embarazo de su todavía marido, tal y como se regula en los arts. 225 y 226 Cc colombiano o $206 \mathrm{Cc}$ guatemalteco. En Cuba, por su parte, se exige un certificado médico de embarazo a la contrayente que pretenda celebrar un matrimonio durante los 300 días antes de la

${ }^{56}$ Existe un Proyecto de Ley núm. 11522-07 de Congreso de los Diputados, de 30 de noviembre de 2017 (Modifica el Código Civil para permitir que la mujer embarazada contraiga segundas nupcias y regula la presunción de paternidad), disponible https:// corraltalciani.wordpress.com/tag/presuncion-pater-is-est/ (consultado el 8 de septiembre de 2019), donde se propone agregar un art. 184 bis al Cc para disponer que si el niño nace antes de los trescientos días desde la terminación del matrimonio o acuerdo anterior pero antes del plazo mínimo del embarazo contado desde la celebración del nuevo vínculo, se presumirá la paternidad del anterior marido o conviviente. Por el contrario, si el niño nace después del plazo mínimo del embarazo contado desde la celebración del siguiente matrimonio o acuerdo de unión civil, la presunción de paternidad se aplicará respecto del nuevo marido o conviviente aunque el nacimiento se haya producido dentro de los trescientos días desde la disolución del anterior vínculo.

${ }^{57}$ Agregado por el art. 27 de Ley núm. 0, publicada en Registro Oficial Suplemento 526 de 19 de Junio del 2015 (Registro Oficial $\mathrm{N}^{\circ}$ 526, de 19 de junio de 2015) que dispone: La acción de impugnación de paternidad o maternidad podrá ser ejercida por: 1. Quien se pretenda verdadero padre o madre; 2. El hijo; 3. El que consta legalmente registrado como padre o madre y cuya filiación impugna; 4. Las personas a quienes la paternidad o maternidad impugnable perjudique en sus derechos sobre la sucesión de los que constan legalmente como padre o madre. En este caso, el plazo para impugnar será de ciento ochenta días contados a partir de la defunción del padre o madre.

${ }^{58}$ Esta normativa ha sido modificada por Decreto Legislativo núm. 1297 para la protección de niñas, niños y adolescentes sin cuidados parentales o en riesgo de perderlos (D.O. El Peruano, 24 de agosto de 2018), que se puede consultar en https://busquedas.elperuano.pe/normaslegales/decreto-legislativo-que-fortalece-la-proteccion-integral-de-decreto-legislativo-n-1377-1684460-1/

${ }^{59}$ El precepto fue modificado por la Ley 39 de 30 de abril de 2003 (Gaceta Oficial 24,794 de Panamá de 6 de mayo de 2003), que puede consultarse en https://docs.panama.justia.com/federales/leyes/39-de-2003-may-6-2003.pdf 
extinción de su anterior enlace (arts. 6.1 CF cubano y 62 de la Ley de Registro del Estado Civil) ${ }^{60}$. Tal exigencia registral opera como presunción iuris tantum de paternidad respecto del ex cónyuge (art. 6.3 del CF cubano) ${ }^{61}$.

24. Del análisis comparativo de estas legislaciones iberoamericanas, observamos que todas siguen parámetros y alineaciones muy similares dentro de un esquema normativo de la presunción de paternidad matrimonial, aunque presentan diferencias, aclaraciones o especificidades que, en la mayoría de los casos, son de tipo procedimental y no tanto sustancial. Nos llama la atención las normativas avanzadas que afrontan con una regulación elástica las vías para desvirtuar la presunción matrimonial, como la peruana, panameña o salvadoreña. Existen soluciones llevadas a la práctica registral, como las del Servicio de Registro Civil de Chile, órgano que facilita el que los hijos de padre casado y separado de hecho, pero biológicamente de otro hombre que no es el cónyuge de la madre, sean inscritos en las partidas del Registro Civil a nombre de ese tercero que ha realizado el acto de reconocimiento, bien sea en la propia partida, bien a través de un documento aparte. De esta manera, los funcionarios del Servicio de Registro Civil chilenos terminan por atenuar la aplicación automática de la presunción matrimonial de paternidad e inscriben al hijo con padre diferente al marido de su madre ${ }^{62}$.

\section{La presunción de paternidad legítima y el sistema severo de su destrucción en los ordenamien- tos jurídicos de base islámica}

25. El juego de la presunción de la paternidad del marido en los Código de Estatuto Personal de los países árabes queda ajustado a sus cánones de familia legítima ${ }^{63}$. De esta manera, para determinar la paternidad matrimonial (al firach) se verifica que trascurre seis meses del nacimiento del hijo desde el contrato matrimonial, sea válido, nulo o viciado, y en circunstancias que permitan las relaciones sexuales ${ }^{64}$. Dicho tiempo es fijado en el Corán y que es recogido por todas las escuelas jurídicas sunnies ${ }^{65}$, excepto en el art. 15 del Código egipcio y el art. 51.1 del Estatuto Personal iraquí, que no lo indican expresamente ${ }^{66}$. Este término mínimo de 180 días desde la celebración del enlace

${ }^{60}$ Ley núm. 51, del Estado del Registro Civil, de 15 de julio de 1985 (en adelante Ley del Registro de Estado Civil), Gaceta Oficial Ordinaria núm. 50, de 22 de agosto de 1985. Posteriormente, la Ley del Registro del Estado Civil y su Reglamento han sido modificados en Gaceta Oficial Extraordinaria núm. 38, de 3 de diciembre de 2015, en https://www.gacetaoficial.gob. $\mathrm{cu} /$. Véase también http://www.parlamentocubano.gob.cu/index.php/documento/ley-del-registro-del-estado-civil/ o http://juriscuba.com/legislacion-2/leyes/.Este requisito formal del art. 62 Ley de Registro del Estado Civil actúa de forma auxiliar para evitar la turbatio sanguinis, en relación con el art. 6, segundo párrafo del CF cubano, pero en ningún caso debe interrumpir los trámites matrimoniales de la mujer embarazada.

${ }^{61}$ Se considera que no acreditar el certificado médico durante ese tiempo, es una infracción que acarrea la nulidad relativa o anulabilidad del posterior matrimonio, aunque puede quedar convalidado de pleno derecho si transcurrido el plazo de seis meses a partir de su formalización y no se ejercita la acción de nulidad (arts. 45 inciso 3; 47, párrafos primero y segundo CF cubano). Vid. O. Mesa CAStillo, "La formalización del matrimonio ante notario y registrador del estado civil", en L. B. Pérez-Gallardo y I. Lora-Tamayo Rodríguez (coords.), Derecho notarial, tomo III, La Habana, edit. Félix Varela, 2008, pp. 204-205, en https://clasesvirtuales.ucf.edu.cu/pluginfile.php/10266/mod_folder/content $/ 0 /$ Textos\%20B\%C3\%A1sicos/La\%20 formalizacin\%20del\%20matrim....doc?forcedownload=1. (consulta 6 de mayo 2020). Asimismo, véase B. L. PÉREZ GALLARDO, "Luces y sombras en torno a la regulación jurídica de la filiación..." loc. cit., pp. 68-70.

${ }^{62}$ Véase a E. Gandulfo Ramírez, "Revisión de la paradoja de la regla de paternidad marital. Un examen analítico...", loc. cit., en espec. pp. 101 y ss.

${ }^{63}$ Como en el art. 154 Código de Familia marroquí (en adelante, CFM), en el que la filiación paterna legítima establecida por presunción al firach queda condicionada a que el hijo nazca al menos seis meses después de la fecha de la conclusión del matrimonio o durante el año siguiente a la disolución del enlace conyugal, siempre que haya existido la posibilidad real o supuesta de que los cónyuges hayan mantenido relaciones sexuales.

${ }^{64}$ C. Ruiz de Almodóvar, "La filiación en los Códigos de Estatuto Personal de los Países Árabes", MEAH. Miscelánea de Estudios Árabes y Hebraicos. Sección árabe-islám, 2011, vol. 60, pp. 255-277, en espec. 257.

${ }^{65}$ C. Ruiz de Almodóvar, "La filiación en los Códigos de Estatuto Personal...”, en espec. p. 257, que agrupa las regulaciones que recogen el plazo mínimo para el nacimiento, como son: arts. 42 argelino; 73 bahreiní; 91 emiratí; 156 jordano; 166 kuwaití; 53.a libio; 154.1 marroquí; 60 mauritano; 72 omaní; 87 qatarí; 128 sirio; 100 sudanés; 71 tunecino; 128 yemení.

${ }^{66}$ Ibidem. 
matrimonial se impone en el art. 191 del Código de Familia (en adelante CF) senegalés ${ }^{67}$ o en el art. 154.1 del CF marroquí.

26. La duración máxima que rige tal presunción se fundamenta en el plazo de un año desde la disolución del enlace matrimonial ${ }^{68}$, tal y como establece el art. 154.2 CF marroquí, salvo excepciones del art. 128 del CF yemení ${ }^{69}$ y del art. 43 del CF argelino ${ }^{70}$, que lo fijan en nueve meses y diez meses respectivamente $^{71}$. La justificación de la dilación de un año para amparar la legitimidad del hijo viene vinculada al periodo de $i d d a^{72}$, donde los aún esposos pueden reconciliarse y mantener relaciones sexuales ${ }^{73}$, lo que implica que los tres meses de la posible convivencia de los progenitores sean acumulados a los nueve de embarazo $^{74}$. Con ello se pone fin a la práctica del "niño dormido" en el útero de la madre, teoría aceptada por las cuatro escuelas jurídicas sunníes y a la que se recurría para legitimar al hijo cuando una mujer repudiada, divorciada, separada o viuda tenía un hijo tras haber finalizado su matrimonio ${ }^{75}$. Por su parte, el art. 191 del CF senegalés señala 300 días, mientras que la Sección 165 de la Evidence Act, 2011 de Nigeria ${ }^{76}$ dispone que la presunción de hijo legítimo rige hasta los 280 días posteriores a la disolución del matrimonio ${ }^{77}$.

27. El sistema de filiación legítima en estos sistemas es tan rígido que si se incumple alguno de los requisitos fijados, la paternidad no se establecerá respecto del marido de la madre, a menos que éste la reconozca o la reivindique ${ }^{78}$. En los Códigos kuwaití y mauritano, por su parte, especifican que tampoco se determina la filiación si el esposo es impúber o no es fértil o tenga un impedimento congénito o patológico que impida la consumación ${ }^{79}$.

${ }^{67}$ Aprobado por Ley 72-61 del 12 de junio de 1972 sobre el Código de Familia (J.O. 1972, p. 1295). El texto se puede consultar https://editions-alexandrie.com/subscription/texte/30583-code-de-la-famille--mise-a-jour-2016-

${ }^{68}$ Véase C. Ruiz de Almodóvar, "La filiación en los Códigos de Estatuto Personal...”, que enumera los preceptos que regulan el plazo máximo: arts. 73 bahreiní; 15 egipcio; 91 emiratí; 156 jordano; 166 kuwaití; 53/a libio; 61 mauritano; 72 omaní; 87 qatarí; 128 sirio; 100 sudanés; 35 tunecino.

${ }^{69} \mathrm{Vid}$. la traducción de estos preceptos en C. Ruiz de Almodóvar, "El Código Yemení de la Familia", Miscelánea de Estudios Árabes y Hebraicos, Sección Árabe-Islam, 2005, núm. 54, pp. 203-265, en espec. p. 225; C. Pérez Beltrán, "Nuevas modificaciones del Código argelino de la familia: estudio introductorio y traducción", Miscelánea de Estudios Árabes y Hebraicos, Sección árabe-islam, 2005, núm.54, pp. 134-167.

${ }^{70}$ Loi no 84-11, de 9 juin 1983 portan le Code de Famillle, modifiée et completée, en https://www.joradp.dz/TRV/FFam. pdf. Sobre la filiación en Derecho argelino, véase N. Aïт-ZAï, "Algérie: la filiation Dans le mariage et hors mariage. La kafala", L'enfant en Droit musulman (Afrique, Moyen-Orient). Actes du colloque du 14 janvier 2008, Paris, Société de législation comparée, 2008, pp. 317-322.

${ }^{71}$ Vid. la traducción de estos preceptos en C. Ruiz de Almodóvar, “El Código Yemení...”, loc. cit.; C. Pérez Beltrán, "Nuevas modificaciones del Código argelino...", loc. cit.

${ }^{72}$ El periodo de abstinencia sexual. Como es sabido, este lapsus de tiempo tiene por objetivo principal comprobar que antes de abandonar el domicilio conyugal, la mujer no se encuentra embarazada y así evitar problemas de filiación y de herencia.

${ }^{73}$ En Derecho musulmán, puede que el varón mantenga relaciones sexuales con una mujer que todavía se encontraba en periodo de incapacidad para nuevas nupcias o $i d d a$, por lo que el acceso carnal deberá igualmente considerarse "consumado bajo presunción errada de licitud" (subha). Si el alumbramiento se produce pasado dicho periodo se atribuirá al esposo putativo la paternidad legítima del nacido y no podrá quebrarse tal presunción, salvo por la declaración de imprecación de adulterio (l'iam). Vid. , L. Milliot et P. Blanc, Introduction à l'étude du droit musulman, 2a edic., Paris, Dalloz,2001, pp. 405-407.

${ }^{74}$ Sobre el periodo mínimo y máximo del embarazo, vid. A. DАнНАK, Los litigios en relación con la filiación de los hijos, Facultad de Derecho, Ciencias Jurídicas y Económicas, Universidad Mohamed V de Rabat, 2003-2004, pp. 31-36 (en árabe, traducción propia); N. J. Coulson, Historia del Derecho Islámico. Trad. Ma Eugenia Eyras, Barcelona, Bellaterra, 1998, p. 183; S. A. Santana Talavera, "El plazo legal de espera en la mujer islámica”, Cadernos de Dereito Actual, 2016, núm. 4, pp.153-184, en esp. pp. 170 y ss.; M. MaseehUl-Uloom, "Rules and regulations of the Iddat", 2010, en https://thequranblog. files.wordpress.com/2010/09/rulesoftheiddat.pdf (consulta: el 22 de julio de 2019).

75 Vid. C. Ruiz de Almodóvar, "La filiación en los Códigos de Estatuto Personal...”, loc. cit., pp. 257-258.

${ }^{76}$ En el norte de Nigeria, la ley de la Sharia ha estado en vigor pero limitada al derecho de familia, por ejemplo litigios relacionados con herencias, con el matrimonio, la familia, el estado civil.

${ }^{77}$ M.O. Izzi y C.D. LongJohn, "An analysis of The concepts of legitimacy and legitimation under Nigerian Family Law", The Journal of Property Law and Contemporary Issues, vol. 5, núm. 1, January 2017, pp. 180-195; J. A. AJonumaH LLM ACIArb y O. Dublin-Green LLM, "Paternity, Illegitimacy and Customary Acknowledgment in Nigeria: A Re-Evaluation", International Journal of Business \& Law Research, vol. 7, núm. 2, April-June, 2019, pp. 112-119.

${ }^{78}$ Arts. 15 egipcio; 168 y 169.b) kuwaití; 53.c) libio; 62 mauritano; 129.2) sirio; 69 tunecino. Vid. C. RuIz de Almodóvar, "La filiación en los Códigos de Estatuto Personal...", loc. cit., p. 258.

79 Ibidem. 
28. Todo ello conduce a mantener un régimen severo para desvirtuar la paternidad legítima, denominado l'iam, que se basa en juramento realizado por el marido delante del juez ${ }^{80}$. La regulación para negar lo que se presume como cierto $^{81}$ viene establecida en diversos Estatutos Personales, como, por ejemplo, en el art. 153.2 $\mathrm{CFM}^{82}$. Por su parte, algunas legislaciones, como en los CF bahreiní (art. 78), CF emiratí (arts. 96 y 97), CF jordano (art. 163), CF kuwaití (arts. 176-179) y CF omaní (arts. 78 y 79), recogen un periodo determinado que para poder negar la paternidad. De esta manera, el marido tiene que declarar el adulterio de su esposa en un tiempo fijado desde el día del nacimiento o desde que tenga conocimiento de este hecho, a condición de que no haya reconocido dicha filiación explícita o implícitamente y presentar oficialmente dicha acusación jurada de adulterio de su esposa en el tiempo convenido. Otras regulaciones, como en los Códigos jordano (art. 164), omaní (art. 78), qatarí (art. 151) o yemení (arts. 109 y 110), ofrecen la fórmula exacta para el juramento de adulterio y negación de la paternidad.

29. En definitiva, los Estatutos personales de base jurídica musulmana mantienen una regulación estricta de la presunción de paternidad legítima y un procedimiento arcaico y discriminatorio para su destrucción. Todo ello con la finalidad de no perjudicar la estabilidad de la familia legítima y la defensa de la paz familiar, que acaban sacrificando la verdad real en materia de filiación. En dichos ordenamientos jurídicos, la situación de los hijos ilegítimos, desgraciadamente, carece de cualquier derecho respecto de su progenitor biológico, salvo en el tunecino ${ }^{83}$, al no contemplarse ni el establecimiento voluntario ni la investigación de la paternidad fuera del marco de la filiación legítima. Precisamente, la preocupación de estos Estatutos Personales por distinguir entre la legítima y la ilegítima, atribuyendo únicamente efectos jurídicos a la primera, acabará por enfrentarse al sistema jurídico español si, en la aplicación de la norma de conflicto en materia de filiación, conduce a tenerlos presentes.

\section{Las inscripciones de nacimiento en el Registro Civil español y el acceso de la paternidad con- tenida en certificación extranjera}

\section{La inscripción de nacimiento en España y la paternidad constatada en el extranjero}

30. En España, el asiento registral de nacimiento desencadena efectos jurídicos verdaderamente importantes, lo que justifica el control de lo contenido en las certificaciones extranjeras aportadas para

\footnotetext{
${ }^{80}$ El término l'iam deriva del verbo maldecir. El procedimiento consiste en que el matrimonio se presenta ante el juez o cadí para que el demandante realice su juramento de anatema mediante una acusación jurada de adulterio y una denegación imprecatoria de paternidad ante el juez o cadí. El Derecho islámico posibilita al marido la acusación a su esposa de adulterio sin prueba jurídica y el rechazo de la paternidad de un niño nacido de ella. Conforme ordena el Corán, el esposo pronuncia cuatro veces el juramento: "juro por Alah, el Único, que he visto a esta mujer en adulterio. Juro por Alah, el Único, que su preñez no se debe a mis obras". En un momento posterior, se realiza un quinto juramento consistente en declarar que no es impostor y que no acusa de forma injusta a la mujer. La esposa culpada puede aceptar la denuncia o replicar mediante cinco juramentos. Por más que el juramento de la esposa neutralice al de su cónyuge, será repudiada y el matrimonio será disuelto. El cadí no hace más que refrendar con su sentencia el hecho declarado por el marido. En cuanto a la filiación del niño, la paternidad legítima queda impugnada. Para profundizar sobre dicho procedimiento, véase Y. LinANT DE BELlefonds, Traité de droit musulman comparé, t. III, Paris, Mouton et Co., 1973, pp. 42-47.

${ }^{81}$ Arts. 78 bahreiní; 90/4 y 97/1 emiratí; 157/c-d y 163 jordano; 176-177 kuwaití; 53/d libio; 151, 153 y 159 marroquí; 68 mauritano; 79/a omaní; 96 qatarí; 129/3; sirio; 75 tunecino, 110 yemení. Vid. C. RuIz de Almodóvar, "La filiación en los Códigos de Estatuto Personal...", loc. cit., p. 258.

${ }^{82} \mathrm{El}$ art. 153.2 CFM dispone que solamente el marido podrá impugnar su paternidad y va a corresponder al mismo las pruebas probatoria que respalden las alegaciones de su demanda judicial. No obstante, la Guía práctica del CFM se informa a la esposa de la posibilidad de solicitar ante el juez la prueba de ADN para demostrar la mentira del marido que niega la paternidad mediante el procedimiento del l'iam. Vid. el art. 153 de la guide practique du code de la famille, http://ejustice.justice.gov.ma / justice/console/Uploads/Doc/guidecodefamille.pdf.

${ }^{83}$ La filiación natural o filiación fuera del matrimonio en Túnez se regula en la Ley nº 98-75 de 28 octubre 1998 relativa a la atribución de un apellido patronímico de los menores abandonados o de filiación no conocida (Journal officiel de la République tunisienne $\mathrm{n}^{\circ} 87$, de 30 octubre 1998), en http://www.legislation.tn/fr
} 
tal fin ${ }^{84}$. La garantía de seguridad que ofrecen las inscripciones del Registro Civil obliga a una verificación de la legalidad del documento aportado y de las declaraciones complementarias mediante la potestad calificadora del Encargado ${ }^{85}$. Todo ello para llegar al convencimiento de que no hay dudas acerca de la realidad del hecho y de la legalidad conforme a la ley española.

31. En la inscripción de nacimiento del naturalizado español, por ejemplo, el Encargado del Registro consigna su filiación cuando éste accede a la nacionalidad española, mención que deriva del nombre y apellidos de los progenitores y del estado civil de éstos. Si estos datos resultan de las certificaciones extranjeras, existe una cierta perplejidad a la hora de aplicar la normativa registral respecto de la inscripción de títulos extranjeros en el Registro Civil español. Actualmente, para tal fin, existe una situación que genera cierta perplejidad a la hora de aplicar la normativa registral respecto de la inscripción de títulos extranjeros en el Registro Civil español. Hasta la definitiva entrada en vigor de la LRC 20/2011 ${ }^{86}$, son aplicables los arts. 23, 26 y 27 Ley de Registro Civil de 1957 (en adelante LRC de 1957) y los arts. 80 a 91 Reglamento de Registro Civil de 1958 (en adelante RRC). No obstante, la confusión se ve agravada por la coexistencia de la Ley de Cooperación jurídica internacional en materia civil ${ }^{87}$ (en adelante LCJIC) y la Ley de Jurisdicción Voluntaria ${ }^{88}$ (en adelante LJV), que regulan ambas, de manera distinta, los requisitos de acceso al Registro Civil de los títulos extranjeros de jurisdicción voluntaria ${ }^{89}$.

32. En lo que refiere a la comprobación del vínculo de paternidad del documento extranjero aportado, y sin prejuzgar el contenido del Derecho foráneo sobre las formas o títulos de determinación de la filiación ${ }^{90}$, la validez del mismo se va a condicionar a que ofrezca garantías análogas a las exigidas para la inscripción por la ley española (arts. 23 de la LRC de 1957 y 85.1 RRC) $)^{91}$. Estas garantías se re-

${ }^{84}$ El riguroso control llevado a cabo por la autoridad registral española de las certificaciones de actas emitidas por Registros extranjeros (como nacimientos, matrimonio, divorcios...) muestra el aumento de falsificaciones y su rechazo como títulos de inscripción. En particular, si existe contradicciones, errores aritméticos, enmiendas o tachaduras, máxime cuando procede del algún país en el que existan precedentes de engaños, como las actas de Registros civiles de Guinea Ecuatorial o de República dominicana. Para evitar tales fraudes, surge la Instrucción de 20 de marzo de 2006 de la DGRN sobre prevención del fraude documental en materia de estado civil, que recoge criterios y orientaciones prácticas para prevenir estas simulaciones, tal y como dispone la Recomendación núm. 9 de la CIEC. Muestra de ello, vid. la RDGRN (4ª) de 25 de noviembre de 1998, Boletín del Ministerio de Justicia, núms. 1851-1852, pp. 2579-2581.

${ }^{85}$ El control de legalidad actúa para vetar el acceso al Registro Civil de los actos inexistentes, inválidos o ineficaces, dotando al Encargado de poderes de calificación. También le permite adoptar cautelas tendentes a garantizar la exactitud de los hechos inscribibles ( $c f r$. J. M. Díaz FraILE, "Breve esbozo de una teoría general sobre los principios registrales civiles. Particular estudio de la publicidad material del Registro civil”, Revista Crítica de Derecho Inmobiliario, año 78, núm. 672, 2002, pp. 1367-1404, esp. pp. 1370-1371).

${ }^{86}$ Cuando entre en vigor esta normativa registral, serán aplicables las normas de los arts. 94 a 100 de dicho texto, en su última versión reformada.

${ }^{87}$ BOE núm. 182, de 31 de julio de 2015.

${ }^{88}$ BOE núm. 158, de 3 de julio de 2015.

${ }^{89}$ Dicha confusión ha sido puesta de relieve de manera unánime por la doctrina internacionalista y, concretamente, en relación con las normas de derecho internacional privado contenidas en los arts. 11 y 12, y Disposición adicional tercera de la Ley de Jurisdicción Voluntaria, como expone contundentemente I. Heredia Cervantes, "Eficacia en España de actos extranjeros de jurisdicción voluntaria", Persona y familia en el nuevo modelo español de Derecho internacional privado, Valencia, Tirant lo Blanch, 2017, pp. 105-133, que considera que "el contenido de estos preceptos, y en particular los dos primeros, constituye un compendio de todo lo que no debería hacer un legislador que merezca dicho nombre. También vid. P. A. De Miguel Asensio, "La ley de jurisdicción voluntaria y Derecho internacional privado", $A E D I P r$, t. XVI, 2016, pp. 147-197, en espec. p. 184.

90 Tenemos que tener presente que los títulos para practicar la inscripción registral de la filiación escapan al ámbito de la normativa de conflicto del art. 9.4 Cc y quedan sometidos a la ley española en tanto lex loci registrationis. De ahí que puedan producirse algunas divergencias entre los medios de determinación de la filiación fijados por la lex causae y sus vías de acceso al Registro previstas por la lex loci registrationis. Si ello es así, corresponderá a la autoridad registral conciliar lo dispuesto en la ley del Registro español sobre la suficiencia o no del título para inscribir la filiación y lo previsto en la lex causae, como normativa aplicable a los medios de establecimiento de tal filiación. La realidad de la práctica registral es que se desprecia claramente la norma de conflicto para la inscripción de nacimiento, que se realizará conforme a Derecho español.

${ }^{91}$ S. Salvador GutiérRez, "Inscripción registral de títulos extranjeros. Inscripción de matrimonios y sus crisis, y régimen económico matrimonial", en M. Herranz Ballesteros y M. Guzmán Zapater (dirs.), Crisis matrimoniales internacionales y sus efectos. Derecho Español y de la Unión Europea. Estudio normativo y jurisprudencial, Valencia, Tirant lo Blanch, 2018, pp. 652-720, en espec. pp. 675-687. 
fieren a la regularidad extrínseca o autenticidad de dicha certificación, como son la legalización o aposti$11 a^{92}$ y traducción (art. 323.2.2 $2^{\circ}$ LEC). Con la entrada en vigor de la LRC 20/2011, se tendrá en cuenta lo dispuesto en sus arts. 95 y 98 para el acceso al Registro civil español de la certificación de extranjera que contenga datos de filiación. Aunque no se haga mención expresa en la LRC 20/2011, para poder inscribir la filiación será imprescindible que no exista ninguna otra contradictoria o que no haya sido modificada en el Registro Civil español por resolución firme ${ }^{93}$. A la autoridad registral española se le impone la obligación de controlar la regularidad extrínseca o autenticidad de la certificación extranjera, como son la legalización o apostilla y traducción, a menos que el Encargado del Registro Civil español conozca el idioma en el que se halla redactada o le conste su autenticidad o aquél llegue por vía oficial o diligencia bastante (art. 95 de la LRC 20/2011) ${ }^{94}$. En este sentido, tenemos que tener presente desde febrero de 2019 que si los ciudadanos presentan un certificado de nacimiento expedido por las autoridades de un Estado miembro ante las autoridades de otro país de la Unión Europea, el Reglamento (UE) 2016/1191 del Parlamento Europeo y del Consejo, de 6 de julio de 2016, por el que se facilita la libre circulación de los ciudadanos simplificando los requisitos de presentación de determinados documentos públicos en la UE y por el que se modifica el Reglamento (UE) núm. 1024/2012 $2^{95}$ lleva a suprimir el requisito de apostilla y simplificar los trámites de las copias certificadas ${ }^{96}$ y las traducciones ${ }^{97}$.

33. Por otro lado, se deben superar las condiciones de eficacia intrínseca del certificado del acta del Registro extranjero aportado para su inscripción, conforme al vigente art. 323.2.1 ${ }^{\circ} \mathrm{LEC}$, que también desarrolla el art. 98 de la LRC 20/2011. Ello consiste en dos tipos de controles. En primer lugar, hay que examinar que la certificación ha sido expedida por autoridad extranjera competente conforme a la legislación de su Estado ${ }^{98}$. Dicha exigencia se basa en la necesidad de un mínimo de contacto con el Estado donde la situación jurídica se ha constituido, sobre todo para verificar la ausencia de fraude de ley por parte de los interesados. En este sentido, se requiere que el Registro extranjero "sea regular y auténtico, de modo que el asiento que se certifica, en cuanto a los hechos de los que da fe, tenga garantías análogas

${ }^{92}$ Se procede a la legalización del documento extranjero, salvo que provenga de un país miembro del Convenio de La Haya de 5 de octubre de 1961, por el cual se suprime la exigencia de legalización y se establece la apostilla (art. 88 RRC, art. 95 LRC 20/2011 y art. 323.2.2 ${ }^{\circ}$ LEC 2000). Tampoco hace falta ningún trámite legalizador en los supuestos en que resulte de aplicación una serie de Tratados internacionales sobre la temática, entre ellos, el Convenio europeo ( $\mathrm{n}^{\circ} 63$ del Consejo de Europa) relativo a la supresión de la legalización de documentos extendidos por los agentes diplomáticos y consulares, hecho en Londres el 7 de junio de 1968. Tampoco será necesaria la legalización si, para el acceso al Registro Civil, al Encargado del Registro le conste su autenticidad, directamente, o por haberle llegado el documento por vía oficial (art. 89 RRC).

${ }^{93}$ Es posible que la rectificación efectuada en el extranjero que contradiga una inscripción de filiación existente en España no se hubiera efectuado por sentencia judicial, sino por otros cauces que concedieran la misma veracidad y legitimidad que la vía jurisdiccional. Para hacer valer el nuevo estado de filiación, y según los arts. 27.2 de la LRC 20/2011 y. 82 RRC, la rectificación válidamente realizada el extranjero solamente podrá registrarse mediante resolución firme recaída en juicio ordinario, siempre que haya obtenido el correspondiente exequatur. Las normas sobre rectificación en la LRC 20/2011 se encuentran en el capítulo II del texto (arts. 90 y 91). En general, sobre esta problemática vid. S. Álvarez GonzÁLEz, Filiación hispano-suiza, León, Universidad de León, Servicio de Publicaciones, 1989, pp. 278-279; M. VIRGós Soriano, "Nota a la Resolución DGRN de 10 de enero de 1984", REDI, 1984-2, vol. XLVI, pp. 670-674.

${ }^{94}$ La eficacia de los documentos públicos extranjeros en el ámbito del Registro Civil tiene un especial tratamiento. El art. 95.2 LRC 20/2011 exime de legalización y de toda formalidad análoga a los documentos que llegan por vía oficial, o si al instructor del expediente le consta su autenticidad directamente o por diligencia bastante.

${ }^{95}$ DOUE L 200/1, 26 de julio de 2016

${ }^{96}$ El Reglamento simplifica otros trámites relativos a las copias certificadas, en la medida en que excluye la exigencia de presentación cumulativa del original de un documento público y de una copia certificada del mismo, al tiempo que obliga a aceptar la presentación de una copia certificada realizada en otro Estado miembro (art. 5).

${ }_{97}^{97}$ Para facilitar la traducción de los documentos públicos incluidos en su ámbito de aplicación, el Reglamento establece impresos estándar multilingües en cada una de las lenguas oficiales de las instituciones de la Unión, para que puedan acompañar al documento público en cuestión, que detalla su contenido (art. 9) y regula las lenguas de expedición (art. 10).

98 Vid. la STS de 9 de febrero de 2009 (Roj: STS 381/2009 - ECLI: ES: TS: 2009:381, CENDOJ, Consejo General del Poder Judicial) que deniega al documento extranjero procedente de República Dominicana el valor de prueba plena a efectos de acreditar el nacimiento y filiación de la solicitante del visado de reagrupación familiar. Y es que la documentación aportada (un acta de nacimiento in-extensa) no ofrecía garantías suficientes en cuanto al parentesco y edad de la solicitante, porque no se ha acreditado que el contenido del acta aportada haga prueba plena en juicio, según el ordenamiento jurídico de la República de Santo Domingo. 
a las exigidas para la inscripción por la Ley española" (arts. 23.2 LRC de 1957 y 85 RRC) ${ }^{99}$. En segundo lugar, habrá que verificar que el Registro extranjero de procedencia tenga, en cuanto a los hechos de que da fe, análogas garantías a las exigidas para la inscripción por la ley española ${ }^{100}$. En estos casos, sin duda, tenemos que tener presente la búsqueda del equilibrio entre el principio general de presunción de validez de los documentos extranjeros de estado civil, el interés general que representa la fiabilidad de los datos del estado civil y los derechos fundamentales del interesado ${ }^{101}$.

\section{Control de las certificaciones de nacimiento extranjeras}

34. Una de las cuestiones menos pacíficas en la práctica es el necesario control o no del hecho o acto contenido en la certificación registral extranjera conforme al ordenamiento designado por las normas españolas de Derecho internacional privado. A pesar de la incertidumbre del actual sistema sobre la interpretación de esta específica exigencia (arts. 323.2.3 ${ }^{\circ}$ de la LEC y el art. 23 de la LRC de $1957^{102}$ ), se puede deducir que la verificación de la certificación extranjera donde conste la inscripción de la filiación tendrá que ajustarse a lo establecido en la leyes designadas por el art. $9.4 \mathrm{Cc}$ para el fondo, el art. $11 \mathrm{Cc}$ para la forma y el art. $9.1 \mathrm{Cc}$ para las cuestiones de capacidad. Ahora bien, dicha aplicación parece que es más teórica que real, pues se desprende de la práctica registral que cuando el acto incorporado en la certificación extranjera no incluya ninguna declaración de voluntad (como puede ser los datos de filiación que se desprende de la situación matrimonial de los progenitores) es inútil el control de fondo, a diferencia de lo que sucedería cuando lo incluido consistía en un reconocimiento voluntario de la filiación, que debía pasar por los control de la legalidad del acto conforme a la legislación española ${ }^{103}$.

35. Esta controversia originó que una línea doctrinal considerara que hay que realizar una interpretación funcional y flexible de los arts. 23 LRC de 1957 y 81 RRC, entendiendo que la vigilancia de la legalidad conforme a la ley española debe limitarse a la observación del orden público internacional español ${ }^{104}$, sin entrar a valorar las condiciones de fondo del acto, aunque sí ha de respetar las normas,

${ }^{99}$ Sobre criterios de la DGRN para la validez de certificaciones y la consideración de regular o no de los Registros Civiles extranjeros vid. E. Rodríguez GaYÁn, "La simulación en España de nacimientos acaecidos en el extranjero: una cuestión de prueba”, Derecho registral internacional. Homenaje a la memoria del profesor Rafael Arroyo Montero, Madrid, Iprolex, 2003, pp. 188-194.

${ }^{100}$ Existen múltiples Resoluciones de la DGRN denegando la inscripción de nacimiento basada en lo contenido en las certificaciones extranjeras por falta de garantías del Registro local, como por ejemplo las RsDGRN procedentes de Bolivia $\left(8^{\mathrm{a}}\right)$ de 26 de Marzo de 2015); de República Dominicana (8a) de 27 de Marzo de 2015; de Venezuela (14 ${ }^{\mathrm{a}}$ ) de 27 de marzo de 2015, Boletín del Ministerio de Justicia, Año LXIX, 19 de agosto de 2015, pp. 8-24.

${ }^{101} \mathrm{Vid}$. las recomendaciones de la Instrucción de 20 de marzo de 2006 de la DGRN sobre prevención del fraude documental en materia de estado civil (BOE núm. 97, de 24 de abril de 2006).

${ }^{102}$ El control de la legalidad del acto incorporado en los documentos extranjeros que pretenden acceder al Registro Civil español es el talón de Aquiles a la hora de otorgar eficacia extraterritorial a dichos documentos, ya que existe bastante incertidumbre en la interpretación de los arts. $323.2 .3^{\circ}$ de la LEC y el art. 23 de la LRC de 1957. Tampoco el apartado V de la Instrucción de 20 de marzo de 2006 de la DGRN, sobre prevención del fraude documental en materia de estado civil, aclaraba cómo se debe vigilar. Concretamente, y tratándose de ciudadanos extranjeros, la ley española debía aplicarse a los supuestos en que entre en juego la excepción de orden público, pero no se determinaba cómo se debía proceder a dicho control, si mediante las reglas españolas de DIPr. o simplemente verificándose que lo contenido en el documento o acto extranjero no fuese en contra del orden público español. Lo que sí mantenía abiertamente era que la ley española debía aplicarse al valorar la legalidad del acto, siempre que afecte a españoles. Con la entrada en vigor de la LRC 20/2011, la descoordinación expuesta queda superada, pues para que acceda lo contenido, sin ninguna distinción, en una certificación de acta registral extranjera debe superar el control de la legalidad del acto incorporado mediante el DIPr. español (vid. arts. 97 y 98).

${ }^{103}$ Al respecto véase C. Ruzz Sutı, Filiación Hispano-Marroqui, Cizur Menor, Cívitas Thomson Reuters, 2011, pp. 290 304, en espec. pp. 306-307.

${ }^{104}$ Solución aportada por A. LARA AgUADO, El nombre en el Derecho internacional privado, Comares, Granada, 1999, pp. 339 y 340, en espec. p. 340; Id., "El caso Niebüll o el derecho al reconocimiento de las certificaciones registrales extranjeras", La Ley, 2006, núm. 6560, año XXVII, pp. 1-6, en espec. p. 4. Esta misma autora aclara que el TJCE exige a los Estados miembros que eliminen el requisito del control de la ley aplicada por la autoridad del Estado de origen y sólo controlen la no contrariedad con su orden público internacional ("El impulso de la ciudadanía de la Unión Europea al reconocimiento intracomunitario de actos 
principios y valores que encarnan nuestro orden público internacional. Ahora bien, vigilar la legalidad del acto incorporado en la certificación extranjera mediante la única fiscalización del orden público internacional español significa imponer una sobrecarga sobre este correctivo, ocasionando que determinadas situaciones fraudulentas fundadas en el extranjero escapen a su vigilancia. Con la entrada en vigor de la LRC 20/2011, la descoordinación expuesta queda superada, pues para que acceda lo contenido tanto en una certificación de acta registral extranjera como en un documento extranjero debe superarse el control de la legalidad del acto incorporado mediante el DIPr. español (vid. arts. 97 y 98), requisito redactado de forma independiente a la revisión del orden público internacional.

36. Particularmente, si se trata de una certificación extranjera que contiene el dato de paternidad, el nuevo art. 98.1 LRC 20/2011 recoge varios controles diferentes ${ }^{105}$. El apartado d) está dedicado a que no resulte manifiestamente incompatible con el orden público español. Bastaría con confirmar que la inscripción de filiación en el Registro extranjero no sea contraria a los principios de igualdad entre los hijos o el de búsqueda de la verdad biológica que rigen en el sistema español ${ }^{106}$.

37. El apartado c) del nuevo art. 98.1 LRC 20/2011 recoge el mecanismo del control de la normativa aplicable a la filiación contenida en la certificación extranjera que pretende inscribirse en el Registro Civil español, lo que implica rechazar los efectos del acto extranjero si no responde a la lex causae localizada mediante la reglamentación conflictual española. En suma, se impone la aplicación del Derecho conflictual del foro sobre lo contenido en la certificación extranjera, lo que puede originar la no admisión como título para practicar la inscripción de la filiación en el Registro Civil español cuando no coincida con las prescripciones conflictuales del Derecho español y generar situaciones claudicantes.

38. Con esta nueva regulación de la LRC 20/2011 comienza, una vez más, el debate doctrinal de la "confrontación metodológica" derivado de la presencia de un requisito "conflictual" entre las condiciones del reconocimiento que aparecen en el art. 98 de la LRC 20/2011, introduciendo la misma rigidez que se achaca al método conflictual. La opción elegida por el legislador español se aleja de una parte de la doctrina internacional, que plantea el reconocimiento de los documentos extranjeros desde el enfoque del sector de la eficacia extraterritorial ${ }^{107}$, eclipsando la utilización del conflicto de leyes ${ }^{108}$ y sin tener tan presente la armonía de soluciones representativa del método de referencia al ordena-

de estado civil (a propósito de la Sentencia del TJCE de 14 de octubre de 2008: Grunkin-Paul y Standesamt Stadt Niebüll)", $L a$ Ley, 2009, núm. 7104, pp. 1-7). Es preciso llamar la atención, como lo hace la doctrina, acerca de la utilización cada vez más frecuente por parte del legislador tanto del ámbito internacional como nacional, del "principio del reconocimiento"(o "principio de la recognoscibilidad") para dar respuesta a las cuestiones que se suscitan, en particular, en lo que se refiere al nombre de las personas físicas, que estaría amparado - a juicio de la doctrina- en la tutela internacional de los derechos del hombre, como destaca S. Tonolo, "Il riconoscimento di atti e provvedimenti stranieri concernenti il diritto al nome nell'ordinamento italiano", Riv.dir.int.priv.e proc., 2009, núm. 4, pp. 849-869, en espec. p. 851. En este sentido también J. RossolilLo, Identità personale e Diritto internazionale privato, Padova, CEDAM, 2009.

105 Vid. A. Lara Aguado, “Artículo 98. Certificaciones de asientos extendidos en el extranjero", en J. A. Cobacho Gómez y A. Leciñena Ibarra (dirs.), Comentarios a la Ley del Registro Civil, Cizur Menor, Thomson Reuters Aranzadi, 2012, pp. 1347-1357.

${ }^{106}$ En este sentido, véase FJ ${ }^{\circ}$ VI de la STS de 17 de abril de 2018 (Roj: STS 1281/2018 - ECLI: ES: TS: 2018:1281, CENDOJ, Consejo General del Poder Judicial), donde se discute sobre la prescripción de la acción de reclamación de la paternidad, que según el Derecho suizo aplicable conforme al art. $9.4 \mathrm{Cc}$ español, establece un plazo de un año en el art. $260 \mathrm{Cc}$ suizo. Y es que la legitimación para impugnar está sujeta a límites, incluidos los temporales, que supone una ponderación de los principios e intereses en juego, como el descubrimiento de la verdad biológica, la tutela judicial efectiva, la estabilidad de la situación del hijo y, sobre todo, el prevalente interés del menor imperante en ambos ordenamientos jurídicos.

${ }^{107}$ Aunque esta metodología conlleva riesgos. Las dificultades inherentes al método de reconocimiento en otras instituciones han sido expuestas por P. LAGARDE, "Développements futurs du droit international privé dans une Europe en voie d'unification: quelques conjectures", RabelsZ, 2004, pp. 225-243.

${ }^{108}$ Tal y como ha declarado elegantemente G. P. Romano, "La bilatéralité éclipsée par l'autorité. Développement récents en matière d'état des personnes", Rev. crit. dr. int. pr., 2006-III, pp. 457-519. 
miento competente ${ }^{109}$. En realidad, según la postura de un sector de la doctrina española ${ }^{110}$, existe un falso problema: si entre las condiciones del reconocimiento consta el verificar la situación a la luz de la ley española, no debería importar que la solución se centrara en un acercamiento de ley aplicable o, en su caso, a una condición de reconocimiento. Llama la atención que este tipo de control conflictual ni siquiera aparezca en el régimen instaurado para el reconocimiento de resoluciones extranjeras ( $v i d$. art. 96 de la LRC 20/2011) ${ }^{111}$. Esta distinción puede estar ocasionada por el privilegio del reconocimiento, que parte de una situación ya existente y en cierta medida cristalizada por el carácter decisional del acto público extranjero, mientras que no lo tendría la situación de la que meramente diera fe un acto público extranjero, que es provisional y puede que no haya pasado filtro alguno.

39. La solución implantada en la LRC 20/2011 llevaría a no beneficiar el favor filii, ya que si se rechaza la inscripción de lo contenido en la certificación extranjera donde consta el dato de la paternidad por no superar los controles exigidos por el Derecho internacional privado español podría, incluso, vulnerar el art. 7 del Convenio de las Naciones Unidas sobre los Derechos del Niño. Por esta razón, se debe procurar la efectividad del derecho del hijo a una sola identidad para la continuidad en la estabilidad del estado civil de filiación en los dos Estados ${ }^{112}$, evitando con ello situaciones claudicantes.

\section{La aplicación del art. 9.4 Cc en el ámbito registral}

40. Al margen del debate metodológico que acabamos de exponer, lo que parece evidente es que el Encargado del Registro Civil español se muestra apático respecto a la aplicación del art. 9.4 Cc en el control de la legalidad de la certificación extranjera que contiene los datos de filiación en los expedientes de nacimiento de los naturalizados españoles y de los que optan o se les atribuye la nacionalidad española ${ }^{113}$.

41. Cuando se produzca la entrada en vigor del art. 98 LRC 20/2011, la autoridad registral española deberá constatar los datos de filiación contenidos en una certificación registral extranjera acorde al art. 9.4 Cc en la versión resultante de la Ley 26/2015, de 28 de julio, de modificación del sistema de protección a la infancia y a la adolescencia que rige para el carácter y los medios de determinación y la filiación ${ }^{114}$. La actual norma de conflicto ha eliminado la problemática del conflicto móvil al fijar la apreciación del punto de conexión en el "momento del establecimiento de la filiación". En consecuencia, se acota las conexiones que han de ser retenidas por el aplicador del derecho, logrando incluso un plus de seguridad jurídica para los particulares.

109 Vid. P. PiCONe, "Les méthodes de coordination entre ordres juridiques en droit international privé", Recueil des Cours, 1999, t. 276, pp. 9-296, en espec. pp. 54-59; P. MAYER, “Les méthodes de la reconnaissance en droit international privé”, Le droit international privé: esprit et méthodes. Mélanges en l'honneur de P. Lagarde, Paris, Dalloz, 2005, pp. 547-574, en espec. p. 564.

${ }^{110} C f r$. S. Álvarez GonzÁlez, "Efectos en España de la gestación por sustitución llevada a cabo en el extranjero: Derecho positivo y propuesta de cambio", AEDIPr, T. X, 2010, pp. 339-377.

${ }_{111} \mathrm{Vid}$. N. Marchal Escalona, “Artículo 96. Resoluciones judiciales extranjeras”, en J. A. Cobacho Gómez y A. LeciÑEna Ibarra (dirs.), Comentarios a la Ley del Registro Civil, Cizur Menor, Thomson Reuters Aranzadi, 2012, pp. 1311-1330.

${ }^{112}$ En general, sobre el reconocimiento internacional del Derecho a la identidad y su vinculación con la identidad biológica vid. S. SAlVAdOr GutiérRez, "Derecho a la identidad", $A C$, 1999, núm. 45, pp. 1469-1497, en espec. pp. 1471-1478; B. GómEZ BENGOECHEA, Derecho a la identidad y filiación. Búsqueda de origenes en adopción internacional y en otros supuestos de filiación transfronteriza, Madrid, Dykinson, 2007, pp. 49-64.

${ }^{113}$ En expedientes de inscripción de filiación paterna, encontramos ejemplos en las Resoluciones de la DGRN 79ª $; 80^{\mathrm{a}} ; 81^{\mathrm{a}}$ y $82^{\mathrm{a}}$ de 11 de diciembre de 2013, Boletín del Ministerio de Justicia, Año LXVIII, 2 de abril de 2014, pp. 21-27; $9^{\mathrm{a}} ; 51^{\mathrm{a}}$ y $52^{\mathrm{a}}$ de 27 de Marzo de 2015, en Boletín del Ministerio de Justicia, Año LXIX, 19 de agosto de 2015, pp. 36-45.

${ }^{114}$ BOE núm. 180, de 29 de julio de 2015. La redacción actual del punto cuarto del art. 9 del Cc se debe al apartado uno del artículo segundo de la Ley 26/2015, de 28 de julio, de modificación del sistema de protección a la infancia y a la adolescencia. Al respecto de la actual normativa conflictual de filiación, véase $\mathrm{M}^{\mathrm{a}}$. D. AdAm MuÑoz, "La nueva regulación de la filiación natural en el derecho internacional privado español", $C D T$, vol. 8, núm. 2, 2016, pp. 34-54; I. Lorente MarTínez, "Filiación natural. El artículo 9.4 del código civil y el triunfo de la residencia habitual del hijo”, CDT, vol. 10, núm. 1, 2018, pp. 592-600. 
42. Ahora bien, el nuevo art. $9.4 \mathrm{Cc}$ español crea una gran incertidumbre a la hora de precisar "el momento" de la ley aplicable para determinar la filiación si el hijo ha tenido su residencia habitual en varios países o ha cambiado de nacionalidad a lo largo del tiempo e, incluso, cuando la filiación aún no está establecida. Precisamente, la consideración del momento de fijación de la paternidad en las inscripciones de nacimiento de los naturalizados españoles puede ser confusa. Lo cierto es que una interpretación literal del art. 9.4.I Cc genera una laguna legal, al no precisar textualmente el momento temporal en el que debe tenerse presente la residencia habitual del hijo o la nacionalidad del mismo ${ }^{115}$.

43. Algunas legislaciones extranjeras han resuelto dicha problemática puntualizando que el momento adecuado es el del nacimiento del hijo ${ }^{116}$. Un sector de la doctrina española considera que lo idóneo para localizar el punto de conexión es el de la presentación de la demanda judicial de filiación ${ }^{117}$, si este fuese el caso. Particularmente, en los expedientes de inscripción de nacimiento, consideramos que para fijar la conexión del art. 9.4 Cc debemos precisar el momento de la inscripción registral del nacimiento del hijo, por ser el más vinculado en el asunto, más aún cuando ya se han desplegado efectos derivados del establecimiento de la filiación. La utilización de este momento puede conducir a ciertos riesgos, pues aunque el nacimiento del hijo dote de seguridad jurídica y certeza al operador jurídico y a las partes implicadas, puede que no exprese la realidad de la relación jurídica de paternidad o maternidad que se trate de establecer, toda vez que el individuo al nacer tuviera su residencia habitual en un país con el que no ha vuelto a tener el más mínimo contacto. De esta manera, se quebraría con el principio de proximidad de la ley aplicada a una determinada relación jurídica.

44. Dado que la fijación del punto de conexión acarrea consecuencias negativas, consideramos que la redacción del art. 9.4.I Cc español hubiera sido más afortunada si el legislador hubiera determinado el momento para la valoración de la residencia habitual o de la nacionalidad del hijo. Este podría haber sido el de la presentación de la demanda o el del inicio del expediente registral de filiación, siempre que se lograra con ello el favor filii, locución que podría servir de cláusula de cierre del precepto. En todo caso, para solucionar dicha cuestión, entendemos que el precepto actual ha de interpretarse en esta dirección.

45. Al parecer, la práctica de la DGRN apuesta por aplicar la ley de la residencia habitual del interesado que tenga momento en que se suscita la problemática derivada del expediente registral concreto $^{118}$. Sin embargo, en otros ámbitos, la DGRN lo precisa de manera diferente. Así, en la determinación de la ley aplicable a la fiscalización del consentimiento y de la capacidad nupcial del contrayente, el Centro Directivo tiene en cuenta la ley nacional del participante que ostentara en el momento exacto de la celebración del matrimonio ${ }^{119}$, rechazando aplicar la que tuviera cuando se promueve el expediente para registrar el enlace.

115 A.-L. Calvo Caravaca y J. Carrascosa González, Derecho internacional privado... pp. 403-404, que exponen que la solución propuesta en el inciso primero del art. $9.4 \mathrm{Cc}$, consistente en congelar los puntos de conexión en el momento de presentación de la demanda ante los tribunales españoles, es adecuada, conveniente y positiva y exponen varias razones. No obstante, mencionan una consecuencia negativa, porque dicha solución puede fomentar las conductas estratégicas y fraudulentas, pues el hijo puede cambiar de nacionalidad o de residencia habitual con el único objetivo de provocar la aplicación de una Ley estatal que le resulta favorable a sus intereses. Se trata, sin embargo, de un inconveniente que posee mecanismos para luchar contra el mismo, a través de la excepción de fraude de ley internacional.

116 Tales como el art. 2632 del Cc y Comercial Argentino, que establece que el establecimiento y la impugnación de la filiación se rigen, alternativamente, por: a) El derecho del domicilio del hijo al tiempo de su nacimiento"; art. 311-14 Cc francés: art. 33 de la Ley italiana de 1995, el art. 28 de la Ley rumana de 1992, o el art. 25.1 de la Ley austriaca de 1978.

${ }_{117}$ Ma. D. ADAm MuÑoz, "La nueva regulación de la filiación natural...", loc. cit., pp. 42 y la doctrina citada en nota 29.

118 Vid. lo dispuesto en el FD $3^{\circ}$ de la RDGRN (33 $)$ de 30 de octubre de 2015, Boletín del Ministerio de Justicia, Año LXX, de 2 de marzo de 2016, pp. 41-45, en el que se destaca que el Centro Directivo prefirió comprobar la vigencia de la presunción de paternidad del marido de la madre en la época de nacimiento de la hija según lo dispuesto en la ley española acorde con la actual residencia habitual de la hija, rechazando el derecho extranjero coincidente con el momento del nacimiento de la menor.

119 Vid. RDGRN de 7 de julio de 2005 (BOE núm. 215, de 8 de septiembre de 2005). En igual sentido, el FJ IV de la RDGRN $\left(18^{\mathrm{a}}\right)$ de 21 diciembre de 2010, Boletín del Ministerio de Justicia, Año LXV, de 1 de octubre de 2011, pp. 519-520; FJ VI de la RDGRN (42 ) de 17 abril de 2015, Boletín del Ministerio de Justicia, Año LXIX 10 de noviembre de 2015, pp. 934-936; FJ ${ }^{\circ}$ VI de la RDGRN núm. 90/2014 de 12 mayo, Boletín del Ministerio de Justicia, Año LXIX, de 21 de enero de 2015, pp. 379-382. 
46. En cualquier caso, entendemos que el art. 9.4.I Cc por el Encargado del Registro Civil sirve para resolver los controles necesarios en el reconocimiento de una situación ya creada en el extranjero. El legislador español ha diseñado una norma de conflicto materialmente orientada que persigue aumentar las oportunidades de acreditación de la filiación del hijo ${ }^{120}$. Por tanto, cualquier opción que sea tomada no puede desconocer que el fundamento del reconocimiento reside en el derecho del individuo a no encontrarse con demasiados obstáculos para procurar la continuidad de su situación en el Estado de acogida. Precisamente, si se traslada este objetivo al ámbito de la filiación tendrá que enlazarse con el favor filii como punto de vista constitucional y apoyado en la normativa legal internacional vigente para España que recoge, defiende y promociona los derechos humanos. Y es que el objetivo central es favorecer al favor filii en la validez de la filiación realizada en el extranjero, junto con el principio de estabilidad de este estado civil. Ello resulta extraordinariamente conveniente, provechoso y apropiado para interpretar la función del art. 9.4.I Cc en relación con la normativa que regula el acceso al Registro Civil español de los documentos extranjeros, que impone el control del acto contenido en ellos mediante las reglas españolas de ley aplicable.

46. En definitiva, desde nuestro punto de vista, la exigencia conflictual planteada en el control de reconocimiento no puede convertirse en el subterfugio legal por excelencia por parte de la autoridad registral española para rechazar cualquier acto que "aparentemente" no cumpla lo impuesto en las diversas leyes que rigen la cuestión de la filiación.

\section{Consecuencias de la filiación paterna contradictoria en el acceso a la nacionalidad española}

\section{Importancia de la inscripción del dato de paternidad en la atribución/opción a la nacionalidad española y en los naturalizados españoles}

47. Con motivo de las solicitudes de inscripción de nacimiento de los naturalizados españoles, de los que optan o se les atribuye la nacionalidad española surgen situaciones de paternidad contradictoria en supuestos de tráfico externo, tal y como se plasma en las múltiples resoluciones de la DGRN. En este epígrafe las hemos dividido en tres grupos, en función de los efectos que produce la no inscripción del dato del padre en el Registro Civil español y su impacto en la fase previa o posterior al acceso a la nacionalidad española.

48. Por un lado, existe un grupo de Resoluciones de la DGRN que niegan el acceso del dato de paternidad recogido en Registros civiles extranjeros, lo que motiva que decaiga el derecho de atribución a la nacionalidad española por ius sanguinis del descendiente de un sujeto español en aplicación del art. 17.1.a) Cc español ${ }^{121}$. En lo que concierne a los nacidos en Venezuela, nuestra autoridad registral viene rechazando la inscripción del dato del padre español por no considerar destruida la presunción de la filiación matrimonial cuando la madre continuaba casada con un ciudadano venezolano en la época del nacimiento del hijo ${ }^{122}$. Por su parte, acerca de los nacimientos ocurridos en Cuba, la

${ }^{120}$ J. CARRASCOSA GonzÁLEz, "Ley aplicable a la filiación por naturaleza: de la ley nacional a la ley de la residencia habitual del hijo", REDI, 2016-II, vol. 68, pp. 157-182.

${ }^{121}$ Como por ejemplo en la citada RDGRN $\left(26^{\text {a }}\right)$ de 23 de febrero de 2018, Boletín del Ministerio de Justicia, Año LXXIII, núm. 2.215, enero de 2019, pp. 28-31.

122 RDGRN (13 $)$ de 27 de marzo de 2015, Boletín del Ministerio de Justicia, Año LXIX, 19 de agosto de 2015, pp. 18-21. Igual respuesta se otorga en RsDGRN $\left(6^{a}\right)$ de 13 octubre de 2008, Boletín del Ministerio de Justicia, Año LXIII, Octubre de 2009, pp. 229-231; (5a) de 6 junio de 2008, Boletín del Ministerio de Justicia, Año LXIII, de 1 al 31 de junio de 2008, pp. 83-85; $\left(5^{\mathrm{a}}\right)$ de 25 de marzo de 2008, Boletín del Ministerio de Justicia, Año LXIII, abril de 2009, pp. 40-42; (2a), de 28 de diciembre de 2010, Boletín del Ministerio de Justicia, Año LXV, de 1 de octubre de 2011, pp. 10-11, donde se dispone que "no procede la inscripción de nacimiento fuera de plazo al no estar acreditado que la persona interesada de nacionalidad venezolana sea hijo o hija de padre español, por estar afectada la filiación por la presunción de paternidad matrimonial que no ha sido destruida". En igual sentido, el FJ V de la RDGRN (4a) de 9 julio de 2008, Boletín del Ministerio de Justicia, Año LXIII, agosto 2009, pp. 103-107, dispone que "según el conocimiento adquirido de la legislación venezolana, en particular el art. 197 del Cc venezola- 
DGRN no recoge el dato de la paternidad en la inscripción de nacimiento fuera de plazo, al no quedar acreditado que el hijo o hija sea de padre español, por estar afectada dicha filiación por la presunción de paternidad matrimonial sin que haya quedado destruida ${ }^{123}$. Con resultado similar, se rechaza inscribir la paternidad de un español respecto de un hijo nacido en Perú de madre peruana que seguía casada en la época del alumbramiento ${ }^{124}$. En el expediente de inscripción dentro de plazo de un nacimiento acaecido en España, el Centro Directivo tampoco considera oportuno registrar la paternidad de un español, ya que la progenitora brasileña mantenía vigente su enlace matrimonial con otro ciudadano español en la época del alumbramiento del hijo ${ }^{125}$.

49. Por otro lado, existe otro grupo profuso de resoluciones de la DGRN relacionadas con iberoamericano de origen que optan a la nacionalidad española en sus diferentes modalidades ${ }^{126}$, y que, sin embargo, tienen dificultades en el acceso de su paternidad en la inscripción de nacimiento ${ }^{127}$ por resultar afectada por la presunción matrimonial. Necesariamente, según dispone el art. 68 de la LRC, el extranjero debe efectuar la inscripción previa de nacimiento antes de inscribirse la nacionalidad española adquirida para que, además, se recojan los datos de su filiación.

50. En la nacionalidad española concedida por opción, el criterio sobre el que gira la actuación de la DGRN se condiciona a la prueba del vínculo de filiación que resulte de la certificación de nacimiento del Registro local extranjero y a su eficacia registral en España ajustada a las garantías de autenticidad y veracidad (arts. 23 LRC y 85 RRC). Por tanto, estando la madre casada cuando tuvo lugar el alumbramiento, es improbable la inscripción de la paternidad extramatrimonial del hijo recogida en la certificación extranjera, salvo que se desvirtúe conforme a la normativa aplicable acorde al art. $9.4 \mathrm{Cc}$ español. Tal negativa comporta la pérdida del derecho de opción basada en el art. 20.1.a) Cc para el que ha estado sujeto a la patria potestad de un español. Precisamente, este es el resultado al que se llega en

no..., si la madre es casada y el alumbramiento ha tenido lugar, como ha sucedido en este caso, estando vigente su matrimonio y antes de transcurridos trescientos días desde la separación legal o de hecho de los cónyuges, es obligado inscribir la filiación matrimonial, dada la fuerza probatoria de la presunción de paternidad del marido de la madre y siendo en este caso el marido y la madre venezolanos. La nacionalidad del nacido será la venezolana hasta que no llegue a desvirtuarse la eficacia probatoria de tal presunción y conste acreditada la paternidad del español quien manifiesta ser el padre biológico...”.

${ }^{123}$ A modo de ejemplo, véase la RDGN 27 de septiembre de 2008, Boletín del Ministerio de Justicia, Año LXIII, Octubre de 2009, pp. 85-86. Por otro lado, la existencia de expedientes de inscripción de filiación paterna son las RsDGRN 79a; 80a $81^{\mathrm{a}} ; 82^{\mathrm{a}}$ de 11 de diciembre de 2013; $9^{\mathrm{a}} ; 51^{\mathrm{a}}$ y $52^{\mathrm{a}}$ de 27 de Marzo de 2015, Boletín del Ministerio de Justicia, Año LXIX, 19 de agosto de 2015 , pp. 36-45.

${ }^{124}$ RDGRN ( $8^{\mathrm{a}}$ ) de 21 de diciembre de 2011, Boletín del Ministerio de Justicia, Año LXVI, 3 de mayo 2009, pp. 7-9.

125 RDGRN de 23 octubre 1995 (RJ 1995\9569).

${ }^{126}$ Las reglas generales de opción quedan recogidas en el art. 20 del Cc español, que van a ser utilizadas para los hijos menores de extranjeros que han adquirido la nacionalidad española. Este derecho de opción queda sujeto a un periodo máximo de hasta dos años después de haber obtenido la mayoría de edad, siempre que el hijo fuera menor de edad cuando su progenitor adquirió la nacionalidad española (art. 20.1.a) Cc español). También, el derecho de opción se efectúa por las personas cuyo padre o madre hubiera sido originariamente español y nacido en España (art. 20.1.b) Cc español), norma destinada a emigrantes o hijos de emigrantes o cuando la madre española perdió su nacionalidad originaria por matrimonio. Al margen de esta regulación y conforme a la DA $7^{\text {a }}$ de la Ley 52/2007, de 26 de diciembre de Memoria Histórica que se reconocen y amplían derechos a favor de quienes padecieron persecución o violencia durante la guerra civil y la dictadura (BOE núm. 310 , de 27 de diciembre de 2007), que se desarrolla en la Instrucción de 4 de noviembre de 2008 (BOE núm. 285, de 26 de noviembre de 2008). Por esta vía son beneficiarios de un derecho de opción a la nacionalidad española las personas cuyo padre o madre hubiese sido originariamente español o los nietos de quienes perdieron o tuvieron que renunciar a la nacionalidad española como consecuencia del exilio pueden formalizar su declaración en el plazo de duración de esta normativa. Al respecto, véase RDGRN (53ª de 30 marzo de 2015, Boletín del Ministerio de Justicia, Año LXIX, 19 de agosto de 2015, pp. 560-564.

${ }^{127}$ Estas inscripciones de nacimiento son consecuencia de la adquisición de la nacionalidad española por ciudadanos cuyo lugar de nacimiento es un país extranjero. En consecuencia, los interesados pueden solicitar, en el momento de levantarse el acta de juramento o promesa de fidelidad al Rey y obediencia a la Constitución y a las Leyes, que se extienda la inscripción de nacimiento en el Registro Civil Municipal correspondiente al domicilio en el que se haya instruido el oportuno expediente registral. En otro caso se estará a la regla general prevista en el art. 16 de la LRC y art. 68 del RRC, por la que "los nacimientos [...] se inscribirán en el Registro Municipal o Consular del sitio en que acaecen [...]. Cuando sea competente un Registro Consular, si el promotor está domiciliado en España, deberá practicarse antes la inscripción en el Registro Civil Central [...]”. 
las solicitudes de inscripciones de nacimiento concernientes a los optantes menores colombianos ${ }^{128} \mathrm{o}$ venezolanos ${ }^{129}$, residentes en sus países de origen e hijos de padre español. En relación con el derecho de opción del art. 20.1.a) de los menores cubanos y con residencia en dicho país, existen múltiples resoluciones de la DGRN ${ }^{130}$. Si nos detenemos en alguna de ellas, como la RDGRN (51 $)$ de 26 de Marzo de $2015^{131}$, comprobamos que el control de los datos de la filiación contenidos en las certificaciones de nacimiento del Registro civil cubano se vigilan por nuestra autoridad registral conforme al ordenamiento cubano, por ser la ley de residencia habitual del hijo (art. $9.4 \mathrm{Cc}$ español). Por tanto, para controlar la legalidad del dato de la filiación se estará a lo dispuesto en el art. 74 del CF cubano, que recoge una presunción de paternidad matrimonial equiparable a la del art. 116 del Cc español. Como complemento a esta normativa, el art. $6 \mathrm{CF}$ cubano exige aportar una certificación médica de embarazo cuando la mujer divorciada pretenda contraer nuevo matrimonio antes de los 300 días de la disolución. Si no es así, habrá que acudir a la vía judicial ordinaria para establecer la paternidad en dichas circunstancias. Por tanto, la conclusión es que la normativa de la presunción de paternidad y su destrucción contenida en la legislación cubana es similar a la española. A pesar de una práctica registral cubana inadecuada, afirmación que podemos extraer de la doctrina de la DGRN, desde el punto de vista español, dicha paternidad contradictoria queda rechazada.

51. Asimismo, surge la cuestión preliminar de la determinación de la filiación para ejercer la opción a la nacionalidad española de aquellas personas "cuyo padre o madre hubiese sido originariamente español", según quedó previsto en el apartado 1 de la Disposición Adicional Séptima de la Ley 52/2007, de 26 de diciembre ${ }^{132}$. La DGRN deniega el derecho a optar a la nacionalidad española de origen a los ciudadanos cubanos que no acrediten ser hijos de padre que hubiere sido originariamente español si no queda desvirtuada la presunción de paternidad matrimonial de su madre ${ }^{133}$. Tampoco se inscribe del dato del padre español de hijos venezolanos, al no desvirtuar la presunción de filiación matrimonial, perdiendo el derecho a optar a la nacionalidad española de origen por la Ley de Memoria Histórica ${ }^{134}$.

${ }^{128}$ RDGRN (2a) de 28 noviembre de 2014, Boletín del Ministerio de Justicia, Año LXIX, del 1 al 30 de noviembre de 2014, pp. 491-494.

${ }^{129}$ RDGN (6 $\left.{ }^{\mathrm{a}}\right)$ de 7 mayo de 2008, Boletín del Ministerio de Justicia, Año LXIII, mayo 2009, pp. 51-53; RDGRN (3a) de 25 de febrero de 2009 (JUR 2010\11127).

${ }^{130}$ Muestra de ello, entre otras, son las RsDGRN $\left(22^{\mathrm{a}}\right)$ de 9 de febrero de 2018, Boletín del Ministerio de Justicia, Año LXXIII, núm. 2.215, enero de 2019, pp. 69-72; ( $\left.1^{\mathrm{a}}\right)\left(2^{\mathrm{a}}\right)\left(30^{\mathrm{a}}\right)$ de 23 de febrero de 2018, Boletín del Ministerio de Justicia, Año LXXIII, núm. 2.215, enero de 2019, pp. 153-160; $\left(3^{\mathrm{a}}\right)\left(4^{\mathrm{a}}\right)\left(5^{\mathrm{a}}\right)\left(6^{\mathrm{a}}\right)\left(7^{\mathrm{a}}\right)\left(12^{\mathrm{a}}\right)$ y $\left(13^{\mathrm{a}}\right)$ de julio de 2018 , Boletín del Ministerio de Justicia, Año LXXIII, núm. 2.219, mayo de 2019, pp.152-167; (1 $\left.1^{\text {a }}\right)$ de 28 de marzo de 2918; (39a) de 23 de marzo de 2018, Boletín del Ministerio de Justicia, Año LXXIII, núm. 2.216, febrero de 2019, pp. 21-23; 221-223; (17 ) de 13 de abril de 2018, Boletín del Ministerio de Justicia, Año LXXIII, núm. 2.216, febrero de 2019, pp. 227-230; (33a) de 6 de abril de 2018, Boletín del Ministerio de Justicia, Año LXXIII, núm. 2.216, febrero de 2019, pp. 22-24. Asimismo, las RsDGRN (54º de 9 de octubre de 2015, Boletín del Ministerio de Justicia, Año LXX, 2 de marzo de 2016, pp. 32-35; (40ª) de 23 de octubre de 2015, Boletín del Ministerio de Justicia, Año LXX, 2 de marzo de 2016, pp. 38-41; $\left(69^{\mathrm{a}}\right)$ de 21 de octubre de 2014, Boletín del Ministerio de Justicia, LXIX, de 1 al 31 de octubre de 2014, pp. 46-48,

${ }_{131}$ Boletín del Ministerio de Justicia, Año LXIX 19 de agosto de 2015, pp. 36-38.

${ }^{132} \mathrm{M}^{\mathrm{a}}$. A. SÁnchez Jiménez, "Ley de Memoria Histórica: el derecho de opción a la nacionalidad española", Boletín Mexicano de Derecho Comparado, año XLII, núm. 125, mayo-agosto de 2009; N. GonZÁLez Martín, "Ley de Memoria Histórica Española. Ley 52/2007 de 26 de diciembre, por la que se Reconocen y Amplían Derechos y se Establecen Medidas a Favor de Quienes Padecieron Persecución o Violencia Durante la Guerra Civil y la Dictadura", Boletín Mexicano de Derecho Comparado, nueva serie, año XLI, núm. 122, mayo-agosto de 2008, pp. 979-991.

${ }_{133}$ Tal y como sucede en las RsDGRN $\left(22^{\mathrm{a}}\right)$ de 9 febrero de 2018, Boletín del Ministerio de Justicia, Año LXXIII, núm. 2.215, enero de 2019, pp. 69-72; (1 $\left(^{\text {a }}\right)$ de 2 de junio de 2017, Boletín del Ministerio de Justicia, Año LXXII, núm. 2209 junio de 2018, pp. 90-94; (3 $\left.3^{\mathrm{a}}\right)$ de 28 de abril de 2017 y (6 $6^{\mathrm{a}}$ ) de 28 de abril de 2017, Boletín del Ministerio de Justicia, Año LXXII, núm. 2207, abril de 2018, pp. 74-85; (10 $)$ de 17 de abril de 2015, Boletín del Ministerio de Justicia, Año LXIX, de 10 de noviembre de 2015, pp. 35-39; (28 $)$ de 26 de febrero de 2016, Boletín del Ministerio de Justicia, Año LXXI, de 7 de marzo de 2017, pp. 319-323; (45ª) de 18 de diciembre de 2015 Boletín del Ministerio de Justicia, LXX, 15 de junio de 2016, pp. 339-342; (17 $)$ de 20 de noviembre de 2015, Boletín del Ministerio de Justicia, Año LXX, 4 de mayo de 2016, pp. 30-32; (55) 2 de octubre de 2015, Boletín del Ministerio de Justicia, Año LXX, 2 de marzo de 2016, pp. 228-232; (43ª 23 de octubre de 2015, Boletín del Ministerio de Justicia, Año LXX, 2 de marzo de 2016, pp. 815-817.

${ }^{134}$ Tal y como se dispone en las RsDGRN (52 $)$ de 1 de abril de 2015, Boletín del Ministerio de Justicia, Año LXIX, 10 de noviembre de 2015, pp. 153-157; (30 $)$ de 1 de abril de 2015, Boletín del Ministerio de Justicia, Año LXIX, 10 de noviembre 
52. En definitiva, la negativa de no inscribir el dato de la paternidad recogido en un Registro extranjero tiene consecuencias registrales para los ya naturalizados españoles de origen iberoamericano - que son, por tanto, plurinacionales-. Principalmente, nos referimos a la no atribución del apellido paterno que debería figurar en la inscripción de nacimiento practicada por la autoridad registral española a raíz de su acceso a la nacionalidad española. Ello se evidencia, en particular, en supuestos de ciudadanos originarios de Colombia ${ }^{135}$, de Ecuador ${ }^{136}$ y, principalmente, de Cuba ${ }^{137}$. En ocasiones, puede existir la posibilidad de inscribir el dato del padre y el apellido paterno cuando se declara probada la separación de hecho del matrimonio de la madre, circunstancia que se desprende, por ejemplo, de una sentencia judicial de divorcio aportada por el interesado, de manera que resulte acreditado que ha transcurrido más de trescientos días desde el nacimiento ${ }^{138}$.

\section{Valoración de la postura de la DGRN}

53. Como hemos adelantado, cuando se procura hacer valer en España una paternidad diferente a la del marido de la madre, la postura general de la DGRN se ajusta a no hacer constar el dato del padre que viene reflejado en la certificación de nacimiento extranjera si colisiona con la presunción de filiación matrimonial del art. $116 \mathrm{Cc}$. Esta solución puede tener mayor o menor transcendencia, dependiendo de los efectos que origine para el interesado. Desde nuestro punto de vista, vamos a evaluar tres aspectos de la postura de la DGRN.

54. En primer lugar, uno de los asuntos que nos sorprende es el uso estandarizado de la aplicación del art. 116 Cc para negar la inscripción de la paternidad por el Encargado del Registro Civil y por la DGRN. Salvo excepciones, como la RDGRN (51 $)$ de 26 de Marzo de $2015^{139}$ donde sí se tiene en cuenta la normativa cubana como lex causae, el art. 116 Cc alcanza a todos los supuestos de filiación, con independencia de si se trata o no de una situación privada internacional, convirtiéndose en una norma material imperativa ${ }^{140}$. La intervención pre conflictual de la norma sustantiva de presunción de la paternidad matrimonial concluirá siempre en la aplicación de la lex fori como forma sencilla de alcanzar la justicia

de 2015, pp. 148-152; (47 $)$ y (48 $)$ de 27 de marzo de 2015, Boletín del Ministerio de Justicia, Año LXIX, 19 de agosto de 2015, pp. 509-518.

${ }^{135}$ Como en las RsDGRN ( $8^{\mathrm{a}}$ ) de 24 de junio de 2016, Boletín del Ministerio de Justicia, Año LXXI, núm. 2198 , de 20 de junio de 2017, pp. 612-615; ( $\left.2^{\mathrm{a}}\right)$ de 28 de octubre de 2016, Boletín del Ministerio de Justicia, Año LXXI, núm. 2202, 6 de noviembre de 2017, pp. 27-30; (32a) 26 de marzo de 2015, Boletín del Ministerio de Justicia, Año LXIX 19 de agosto de 2015, pp. 33-35; ( $\left.2^{\mathrm{a}}\right)$ de 29 de diciembre de 2010, Boletín del Ministerio de Justicia, Año LXV, de 1 de octubre de 2011, pp. 13-14.

${ }_{136}$ RDGRN (40ª de 5 de septiembre de 2012, Boletín del Ministerio de Justicia, Año XLVII, de 20 de marzo de 2013, pp. 4-6.

137 A modo de ejemplo, entre otras, véase las resoluciones de las RsDGRN $\left(6^{\text {a }}\right)$ de 8 de septiembre de 2017, Boletín del Ministerio de Justicia, Año LXXII, núm. 2211, septiembre de 2018, pp. 27-30; (38 $)$ de 7 de abril de 2017, Boletín del Ministerio de Justicia, Año LXXII, núm. 2207, abril de 2018, pp. 9-11; (19ª) de 24 junio de 2016, Boletín del Ministerio de Justicia, Año LXXI, núm. 2198, de 20 de junio de 2017, pp. 45-47.

${ }^{138}$ RsDGRN (34a) de 29 de octubre de 2014, Boletín del Ministerio de Justicia, Año LXIX, de 1 al 31 de octubre de 2014, pp. 51-54; (51 $)$ de 26 de Marzo de 2015, Boletín del Ministerio de Justicia, Año LXIX, 19 de agosto de 2015, pp. 36-38; RDGRN $\left(37^{\mathrm{a}}\right)$ de 23 de marzo de 2018, Boletín del Ministerio de Justicia, Año LXXIII, núm. 2.216, febrero de 2019, pp. 214-217.

${ }^{139}$ Boletín del Ministerio de Justicia, Año LXIX 19 de agosto de 2015, pp. 36-38. Con similar respuesta, vid. el FJ ${ }^{\circ}$ VI de la RDGRN (30 $)$ de 1 de Abril de 2015, Boletín del Ministerio de Justicia, Año LXIX, de 10 de noviembre de 2015, pp. 283287; FJ ${ }^{\mathrm{o}}$ VI de la RDGRN $\left(52^{\mathrm{a}}\right)$, de 1 de Abril de 2015, Boletín del Ministerio de Justicia, Año LXIX, de 10 de noviembre de 2015, pp. 153-157.

${ }^{140}$ Una parte de la doctrina viene calificando a dicha regla con absoluta imperatividad, tal y como expone H. CORRAL TALCIANI, "La filiación matrimonial”, Actualidad Jurídica, Universidad del Desarrollo, Año 4º núm. 7, 2003, pp. 241-262, disponible en https://corraltalciani.files.wordpress.com/2010/04/la-filiacion-matrimonial.pdf (consultado 18 de mayo de 2020). En general, sobre las normas imperativas vid. J. C. FernÁNDEZ RozAs, "Art. 12.6", Comentarios al Código civil y Compilaciones forales, t. I., vol. 2, $2^{\text {a }}$ edic., Madrid, Edersa, 1995, pp. 973 1082; F. J. Garcimartín AlfÉrez, Sobre la norma de conflicto y su aplicación procesal, Madrid, Tecnos, 1994; Рн. Francescakis, "Quelques précisions sur les lois d'application immédiate et leurs rapports avec les règles de conflit de lois", Rev. crit. dr. int. pr., 1966, pp. 1-18; P. KINSCH, "L'autolimitation implicite des normes de Droit privé material", Rev. crit. dr. int. pr., 2003-III, pp. 403-435. 
material que los derechos fundamentales encarnan ${ }^{141}$. No obstante, la citada disposición no debe emerger como una norma material imperativa con alcance internacional, al no aparecer en el ordenamiento español con un alto grado de imperatividad como para autolimitar el alcance del art. 9.4 Cc. Ciertamente, en el Derecho español de filiación predomina la imperatividad interna como rasgo distintivo del sector ${ }^{142}$, tal y como ocurre con la materia especialmente sensible recogida en el art. $116 \mathrm{Cc}$ español. Aunque con la aplicación de esta regla de presunción se podría justificar la salvaguardia del interés público, realmente no se impide el derecho a la búsqueda de la verdad biológica, por lo que la DGRN no debería elevarla a la categoría de una ley de policía con alcance en las situaciones privadas internacionales ${ }^{143}$.

55. Por otra parte, podríamos pensar que la función que cumple la presunción de paternidad matrimonial en el Derecho español vendría vinculada a la imperatividad de la normativa registral. El principio de legalidad que rige en el Registro Civil somete toda su actividad a una cuidadosa reglamentación legal, que se traduce en varias garantías. La primera de ellas sería la exactitud registral conseguida por el único acceso al Registro de los hechos ciertos y debidamente comprobados ${ }^{144}$. La segunda garantía consiste en el control de legalidad a través de la potestad calificadora atribuida al Encargado del Registro (art. 30.2 LRC de 2011), lo que supone la consecución de la legalidad stricto sensu, por tanto lo relativo a la verdad biológica $^{145}$. De ello deriva que si la paternidad matrimonial fundada en el art. $116 \mathrm{Cc}$ finalmente se inscribiera en el Registro Civil español, la persona no identificada como progenitor tendría que reclamar e impugnar la inscrita a través de una resolución judicial, dado que una inscripción registral sólo puede rectificarse mediante sentencia. Por tanto, podríamos entender que la imperatividad del art. 116 Cc vendría determinada por la relevancia de la normativa registral, alcance otorgado por las autoridades registrales españolas para rechazar la inscripción de paternidades contradictorias recogidas en la certificación extranjera. En otros términos, la verificación efectuada para garantizar la adecuación a la realidad vendría derivada de la seguridad de los principios inspiradores del Registro y de la propia función registradora ${ }^{146}$.

56. A pesar de que en ocasiones se podría llegar a este mismo resultado, el control intrínseco de las certificaciones de nacimiento procedentes del extranjero que contienen el dato del padre debe ser

${ }^{141}$ Vid. C. Labrusse, "Droit constitutionnel et droit international privé en Allemagne fédérale: (à propos de la decision du Tribunal Constitutionnel federal du 4 mai 1971)", Rev. crit. dr. int. pr., 1974, pp. 1-46, en espec. p. 20; A. BUCHER, "L'ordre public et le but social des lois en droit international privé", Recueil des Cours, 1993-II, t. 239, pp. 9-116, en espec. p. 43.

${ }^{142}$ En general, el Derecho de familia y sucesorio, distinguido por la imperatividad de sus normas, este carácter va disminuyéndose a favor de la autonomía de la voluntad, tal y como se puede comprobar en las normas conflictuales de los instrumentos europeos de la ley aplicable a las relaciones familiares y sucesorias. Ahora bien, en el marco de una relación caracterizada por la desigualdad estructural de las partes, como la de alimentos, este principio sí queda afectado por limitaciones específicas de orden material que acarrea su derogación total o parcial y un restablecimiento de la conexión objetiva materialmente orientada, como ocurre en el Protocolo de Alimentos y la regla favor creditoris. Sobre el tema, véase N. ChIKOC BARREDA, "Normas de policía, materialización de soluciones y autonomía de la voluntad en DIPR europeo en materia familiar y sucesoria", $A E D I P r$, t. XVIII, 2018, pp. 93-125.

${ }^{143}$ En otros sistemas jurídicos podemos encontrar ejemplos de la existencia de normas materiales imperativas en Derecho de familia, concretamente en la regulación del divorcio, tal y como se puede comprobar en G. Moreno Cordero, "La identidad causal como condición para el reconocimiento en Colombia de las decisiones españolas de divorcio: Incidencia del Reglamento Roma III", Revista Electrónica de Estudios Internacionales, núm. 30, diciembre 2015, pp.1-40, pp.14-24; Id., "El efecto erga omnes del derecho matrimonial colombiano y su impacto en el Derecho internacional privado", Revista Iberoamericana de Derecho internacional y de la Integración, núm. 8 (octubre-noviembre de 2018), pp.1-24, en espec. pp. 7-14; Id., "Las decisiones extranjeras de divorcio frente a la exigencia de conformidad con el derecho del foro: el ejemplo chileno y peruano", Boletín mexicano de Derecho comparado, núm. 155, enero-abril de 2018, pp. 175-226, en espec. pp.194, 195; 214-222.

${ }^{144}$ Vid. F. Luces Gil, Derecho registral civil, $3^{\text {a }}$ edición actualizada, Barcelona, Bosch, 1986, pp. 36-37.

${ }^{145}$ El Encargado tiene limitadas sus facultades de calificación y no puede enjuiciar el fondo. La calificación, a los efectos de extender la oportuna inscripción marginal, está limitada al análisis de la competencia y a la clase de procedimiento seguido, formalidades extrínsecas de los documentos presentados y asientos del propio registro. Sin embargo, aunque las facultades calificadoras del Encargado del Registro civil no alcancen a la comprobación de la veracidad de las declaraciones y no queda, por ello, impedida totalmente la eficacia prima facie de los llamados reconocimientos de complacencia, resulta obvio que, en armonía con el principio de verdad biológica, informador del Derecho español de filiación, se deba rechazar la inscripción del reconocimiento de la filiación cuando el título formal acompañado de las diligencias comprobatorias oportunas se desprenda que el autor no es el padre biológico del reconocido (art. 30.3 de la LRC de 2011).

146 Vid. E. Rodríguez Gayán, Derecho registral civil internacional, Madrid, Eurolex, 1995, p. 44. 
realizado mediante la reglamentación conflictual y descartar la solución registral centrada en la dotación de imperatividad internacional al art. $116 \mathrm{Cc}$. El ordenamiento jurídico al que lleve la aplicación del 9.4 Cc será el encargado de establecer la virtualidad de dicha presunción y los medios para poder destruirla.

57. En segundo lugar, cuando la inscripción de la paternidad no quede constatada por la vía de un expediente gubernativo, la DGRN apuesta por una solución basada en acudir a la vía judicial ordinaria o iniciar un nuevo expediente gubernativo por la parte interesada, siempre que se presenten las pruebas pertinentes que destruyan la mencionada presunción del art. $116 \mathrm{Cc}^{147}$. Esta respuesta puede llevar a resultados insatisfactorios desde el punto de vista de tiempo o incremento económico e, incluso, encontrar ciertas dificultades. Por ejemplo, la vía judicial para reclamar o impugnar la paternidad puede ser inaccesible según la legislación aplicable a la que dirija el art. $9.4 \mathrm{Cc}$ español, ya que al interesado se le impide la acción procesal judicial correspondiente, al quedar prescrita por los plazos de caducidad de las acciones de reclamación o impugnación o, incluso, por falta de legitimación. La solución no reside en derogar las regulaciones sustantivas que contienen la presunción de paternidad matrimonial. Se echan en falta opciones en los sistemas jurídicos que permitan corregir los vínculos paterno-filiales de manera rápida y sencilla, sin necesidad de incurrir en gastos económicos en procesos judiciales, de manera que sean accesibles para los que están siendo perjudicados. Desde nuestro punto de vista, el legislador español no debería permanecer indiferente cuando los hechos y presupuestos en que se funda la presunción de paternidad del marido podrían quedar desvirtuados con ayuda de la ciencia, siempre con el respeto de los derechos fundamentales vinculados al hijo y a los implicados en la determinación de la filiación.

58. En tercer lugar y, por último, a pesar del rechazo de la paternidad constatada en el extranjero, la DGRN ofrece la posibilidad al interesado de solicitar la práctica de una anotación marginal con valor meramente informativo (art. $38.3^{\circ}$ LRC) ${ }^{148}$ en la inscripción de nacimiento, con la finalidad de que consten sus apellidos conforme a la anterior ley personal ${ }^{149}$. A pesar de que esta anotación marginal no constituya la prueba que sí proporciona una inscripción principal, aplaudimos el mecanismo propuesto por la DGRN para evitar los apellidos diferentes en los Estados vinculados del nacido de padre diferente del marido de la madre. No obstante, desconocemos la argumentación legal que ha empleado este Centro Directivo para llegar a esta respuesta. El recurso de la DGRN de conectar con la ley nacional anterior del interesado para poder inscribir su apellido paterno en la inscripción marginal probablemente esté basado en el traslado de lo dispuesto en el art. $199 \mathrm{RRC}^{150}$. Desde nuestro punto de vista, para integrar el vacío argumentativo de dicha solución, se debería acudir objetivamente al art. 1 del Convenio de Múnich relativo a ley aplicable sobre nombre y apellidos ${ }^{151}$, que remite a la ley de la nacionalidad de la persona interesada. Es cierto que, en caso de cambio de nacionalidad de la persona interesada, debe aplicarse la ley del Estado de la nueva nacionalidad. Sin embargo, los naturalizados de origen iberoamericano no son supuestos estrictos de cambio de nacionalidad, porque nos hallamos ante una "doble nacionalidad prevista" del art. 9.9 Cc español. A modo de ejemplo, el que adquiere la nacionalidad española por opción, al igual que el que la consigue por residencia o por carta naturaleza, no renuncia ni pierde su anterior nacionalidad si es de algún país iberoamericano (arts. 23.b y $24.1 \mathrm{Cc}$ español). Así, son dobles nacionales los hijos menores bajo la patria potestad de un español que optan a la nacionalidad española y lo hacen desde su país de origen. La cuestión de sus apellidos se remediará conforme a la ley coincidente con la última residencia habitual o, en su defecto, con la última adquirida

${ }^{147}$ FJ $^{\mathrm{o}} \mathrm{V}$ de la RDGRN (19ª de 24 junio de 2016, Boletín del Ministerio de Justicia, Año LXXI, núm. 2198, de 20 de junio de 2017, pp. 45-47.

${ }^{148}$ La anotación en el Registro civil con valor simplemente informativo es a petición del Ministerio Fiscal o de cualquier interesado (art. 38.4 $4^{\circ}$ LRC 1957 y art. 153 RRC).

${ }^{149}$ RDGRN $\left(57^{\mathrm{a}}\right)$, de 5 de junio de 2015, Boletín del Ministerio de Justicia, Año LXIX, 3 de Diciembre de 2015. Este tipo de solución recuerda al art. 96.1, último párrafo LRC 20/2011, que regula la posibilidad de anotación registral cuando la resolución extranjera carezca de firmeza o de carácter definitivo.

${ }^{150}$ Por el cual: "El que adquiere la nacionalidad española conservará los apellidos que ostente en forma distinta de la legal, siempre que así lo declare en el acto de adquirirla, o dentro de los dos meses siguientes a la adquisición o a la mayoría de edad".

${ }^{151}$ BOE núm. 303, de 19 de diciembre de 1989. 
(art. 9.9 Cc español). Por ejemplo, si tramitan su derecho de opción a la nacionalidad española desde Cuba, habrá que respetar lo contenido en la ley de su residencia habitual cubana. Por el contrario, si lo hacen en España, atenderemos a la ley española. Nos encontramos ante en una especie de esquizofrenia en la interpretación de la normativa aplicable a los apellidos de los naturalizados españoles de origen iberoamericano. Esta materia debería ser aclarada, sin duda, por la DGRN.

\section{Conclusiones}

59. En ciertos países, la realidad variopinta en las relaciones interpersonales tanto intra como extra matrimoniales, ha originado la precariedad de la presunción de paternidad matrimonial para terminar por inscribir la paternidad del hijo de un tercero diferente al marido de la madre por la autoridad registral competente. Ante este contexto, absolutamente trastocado y bloqueado ipso iure, el Registro civil español se ve obligado a rechazar dicha inscripción de la paternidad que, originariamente se registró en el extranjero, y que ahora pretende desplegar efectos en España. Ello, sin duda, merma las expectativas filiales del hijo de mujer casada con padre diferente al marido de su madre.

60. El escenario expuesto surge con motivo de que los ordenamientos jurídicos no articulan adecuadamente el cese de la convivencia marital respecto a la regla pater is est. A pesar de ello, hemos comprobado que ciertas regulaciones, en Derecho comparado existe una relajación de la aplicación de la presunción de paternidad matrimonial por las autoridades registrales, como ocurre en Chile o Cuba, con la finalidad de favorecer la inscripción de la filiación biológica del nacido ${ }^{152}$, a pesar de los inconvenientes que se pueden ocasionar en situaciones futuras.

61. Las deficiencias detectadas en las normativas sustantivas consultadas que regulan la presunción de la paternidad matrimonial producen lo que hemos denominado paternidades contradictorias, problemática que incide en las relaciones de tráfico externo. La resistencia a inscribir la mención de la paternidad en el Registro español cuando pervive la presunción de filiación matrimonial conduce a la no anotación del apellido paterno, además de la negación del resto de efectos vinculados a la relación filial. Justamente, este tipo de situaciones claudicantes surgen con motivo de las solicitudes de inscripción de nacimiento de los naturalizados españoles, de los que optan o a los que se les atribuye la nacionalidad española, tal y como se constata en las múltiples resoluciones de la DGRN.

62. Cuando la autoridad registral española comprueba el vínculo de filiación contenido en las certificaciones extranjeras recurre sorprendentemente al art. $116 \mathrm{Cc}$, esto es, a la definición de la presunción de paternidad matrimonial admitida en nuestro ordenamiento, en lugar de apelar a la ley designada por el art. $9.4 \mathrm{Cc}$. De esta forma, la DGRN le atribuye al a la regla española sobre presunción de paternidad matrimonial de una imperatividad de la que carece, transformándolo en una norma material imperativa con alcance internacional. Sin embargo, debe ser la lex causae, como normativa aplicable a tal filiación, la que debe atender a la vigencia o no de la presunción de paternidad del marido de la madre en la época del nacimiento del interesado, así como verificar las vías existentes para quede desvirtuada.

63. Gracias a la modificación de 2015 del sistema español, la solución del art. 44.4 de la LRC favorece la constatación extrajudicial de la paternidad del hijo de madre casada con persona distinta a la que se declara como padre. En estos casos, únicamente se inscribirá la materna y se procede a la apertura de un expediente registral gubernativo para determinar la filiación paterna. A pesar de ello, esta respuesta no atenúa la problemática de paternidad contradictoria que surge a raíz de las inscripciones de nacimiento de ciudadanos que ostentan más de una nacionalidad o de los que van a acceder a la

${ }^{152}$ Según E. Gandulfo Ramírez, "Revisión de la paradoja de la regla de paternidad marital. Un examen analítico...”, loc. cit., en espec. p. 104, la autoridad registral debería responder a las expectativas mínimas de informar quién es padre a efectos de la ley para que los interesados tomen la vía que corresponda a las expectativas filiales legales. 
nacionalidad española gracias a que su ascendiente es un sujeto español. La dificultad de admisión de pruebas para la destrucción de la presunción iuris tantum de paternidad respecto del ex cónyuge de la madre incrementa la incertidumbre del interesado, que se encuentra sin filiación paterna inscrita. Por ello, consideramos que se debería implantar un sistema más flexible de destrucción de la presunción de paternidad matrimonial. Nos agradará conocer si, en el futuro, se dota de cobertura legal a la prueba del $\mathrm{ADN}$ en el ámbito administrativo/extrajudicial, recurso que minimizará la problemática derivada de las situaciones claudicantes de filiación acusadas por las nuevas realidades del Registro civil español.

64. En definitiva, la presunción de la paternidad matrimonial, a pesar de su decadencia, sigue influyendo en las situaciones privadas internacionales. La negativa de la autoridad registral español de la inscripción de la filiación paterna proveniente del extranjero originada por la aplicación del art. 116 Cc y la influencia de este rechazo en el acceso a la nacionalidad española pone de manifiesto la necesidad de mejorar los derechos del nacido de padre diferente al marido de la madre. Hasta que llegue una transformación profunda del régimen de la presunción de paternidad matrimonial, se precisa por la DGRN de unas directrices para este tipo de situaciones de tráfico externo en relación con la recepción de pruebas sobre la interrupción de la vida conyugal de la madre en la época de la concepción del hijo. Ello podría contribuir a facilitar la constatación de la paternidad en el Registro Civil español de los que ahora vienen siendo perjudicados. 